\title{
The FGF metabolic axis
}

\author{
Xiaokun Li (ه) \\ School of Pharmaceutical Science, Wenzhou Medical University, Wenzhou 325035, China \\ (C) The Author(s) 2019. This article is published with open access at link.springer.com and journal.hep.com.cn
}

\begin{abstract}
Members of the fibroblast growth factor (FGF) family play pleiotropic roles in cellular and metabolic homeostasis. During evolution, the ancestor FGF expands into multiple members by acquiring divergent structural elements that enable functional divergence and specification. Heparan sulfate-binding FGFs, which play critical roles in embryonic development and adult tissue remodeling homeostasis, adapt to an autocrine/paracrine mode of action to promote cell proliferation and population growth. By contrast, FGF19, 21, and 23 coevolve through losing binding affinity for extracellular matrix heparan sulfate while acquiring affinity for transmembrane $\alpha$-Klotho $(K L)$ or $\beta$-KL as a coreceptor, thereby adapting to an endocrine mode of action to drive interorgan crosstalk that regulates a broad spectrum of metabolic homeostasis. FGF19 metabolic axis from the ileum to liver negatively controls diurnal bile acid biosynthesis. FGF21 metabolic axes play multifaceted roles in controlling the homeostasis of lipid, glucose, and energy metabolism. FGF23 axes from the bone to kidney and parathyroid regulate metabolic homeostasis of phosphate, calcium, vitamin $\mathrm{D}$, and parathyroid hormone that are important for bone health and systemic mineral balance. The significant divergence in structural elements and multiple functional specifications of FGF19, 21, and 23 in cellular and organismal metabolism instead of cell proliferation and growth sufficiently necessitate a new unified and specific term for these three endocrine FGFs. Thus, the term "FGF Metabolic Axis," which distinguishes the unique pathways and functions of endocrine FGFs from other autocrine/paracrine mitogenic FGFs, is coined.
\end{abstract}

Keywords FGF19; FGF21; FGF23; FGFR; metabolism; endocrine; Klotho

\section{Introduction}

Fibroblast growth factors (FGFs) are pleiotropic signal molecules for all types of cell and tissue systems in metazoans [1-3]. FGFs share a conserved core structure of $\beta$-trefoil fold consisting of 12 -stranded $\beta$-sheets arranged in three similar lobes around a central axis, of which six strands form an antiparallel $\beta$-barrel $[4,5]$. Except for the four FGF-homologous intracrine factors that are functionally reminiscent of the ancestor FGF, the FGFs can be classified into mitogenic and metabolic FGFs, which overtly regulate cellular proliferation and substrate/energy metabolism, respectively, on the basis of their distinct functions and endpoint biological effects [6,7]. Both FGF classes signal through the same types of transmembrane receptor tyrosine kinases, that is, the FGF receptors (FGFRs) 1 to 4 with multiple splicing variants [8]. However, in physiology, these two types of regulatory

Received July 10, 2019; accepted July 22, 2019

Correspondence: Xiaokun Li, xiaokunli@wmu.edu.cn activities driven by the two FGF classes appear to be spatially and temporally segregated. At a physiological level, mitogenic FGFs appear to be incapable of traveling far to other tissues, including metabolic tissues, to promote cellular metabolism because of local trapping after secretion that is mediated by high affinity binding to the extracellular matrix heparan sulfate (HS). On the other hand, metabolic FGFs circulate but are inactive for nonmetabolic tissues or cells that often undergo active tissue remodeling via the renewed cycles of cell proliferation and population growth because of the lack of critical transmembrane accessory coreceptors. This divergence necessitates a distinction of the metabolic axis that is a term as we call hereafter, which the metabolic FGFs drive, from the mitogenic axis that the mitogenic FGFs drive. The metabolic axis still shares the major aspects of structural coevolution $[9,10]$ while gaining unique structural and functional divergence with the mitogenic axis within each subfamily (Table 1), as our recent structural studies have revealed $[2,5,11]$. From the evolutionary standpoint, although the two axes largely parallel and drive differential effects via divergent intracellular mechanisms, they aim for a common goal of promoting the survival and homeostasis 
of each cell/tissue system and the organism as a whole (Fig. 1), as we have summarized in a previous review [7].

\section{The mitogenic FGF axis}

The classic FGF family consists of 17 structurally related polypeptides, which are secreted and act as extracellular signaling molecules, in humans $[1,3,7,12]$. For the most part of FGF history beginning in the late 1970s [13,14], FGFs are known as short-range mitogens in a wide variety of cell types in the developing ectoderm, mesoderm, and endoderm. FGFs elicit a chemoattractant activity to promote cell migration and tissue remodeling and antiapoptotic effects to promote cell survival. FGF1 and 2 are the prototypes that are initially isolated based on potent mitogenic activity toward fibroblasts or fibroblastlike cells $[13,14]$. It was found early that the mitogenic FGFs bind tightly to the local extracellular matrix HS chains, do not circulate, and accordingly act in a paracrine or autocrine mode. This heparin/HS binding property renders their potent activity temporarily contained but timely released locally upon injury or demand of tissue remodeling [15]. These mitogenic FGFs include 14 members (Table 1), which strongly promote genomic DNA synthesis and subsequent cell division and population growth $[12,16,17]$. Therefore, mitogenic FGFs play critical roles in the development of multiple tissues/organs [18-20]. They initiate the mitogenic axis by binding to the Ig-like ectodomains of their cognate transmembrane
FGFRs in complex with HS motifs on diverse target cells and tissues in the first step $[1,21,22]$. The subsequent activation of the intracellular kinase domains of FGFRs results in downstream signal relay primarily through the PI3K-AKT, RAS-MAPK, and PLC $\gamma$-PKC pathways [2325], as we have summarized previously [3]. These HS and FGFR dependent activities driven by the mitogenic FGF axes contribute not only to the regulation of virtually all aspects of development and organogenesis but also to many natural processes of active post-developmental tissue repair, remodeling, and homeostasis [26].

Among mitogenic FGFs, FGF7, which is also known as keratinocyte growth factor (KGF), has the highest specificity for receptor isotypes [12,22,27]. FGF7 only activates the IIIb-type isoform of FGFR2. Given that FGF7 is produced in mesenchyme cells, while FGFR2IIIb resides on the epithelial or keratinocyte cells, FGF7 forms a unidirectional paracrine communication axis with FGFR2 from mesenchyme to epithelium compartment within a tissue or organ. On the other hand, epithelial cells secrete specific FGFs (e.g., FGF1 or 9), which then acts on mesenchymal cells that harbor FGFR1IIIc within two compartmental tissues. Therefore, these FGF1 and FGF7 driven mutual cell communication axes are poised to drive tissue remodeling and maintain tissue homeostasis [28]. The prolonged or abnormal activation of the FGFR-HS binary complexes by mitogenic FGF axes contributes to an array of cell/tissue-specific developmental diseases and multiple cancer types [3,29] (see a brief summary in Table 1). The proliferation- and survival-promoting

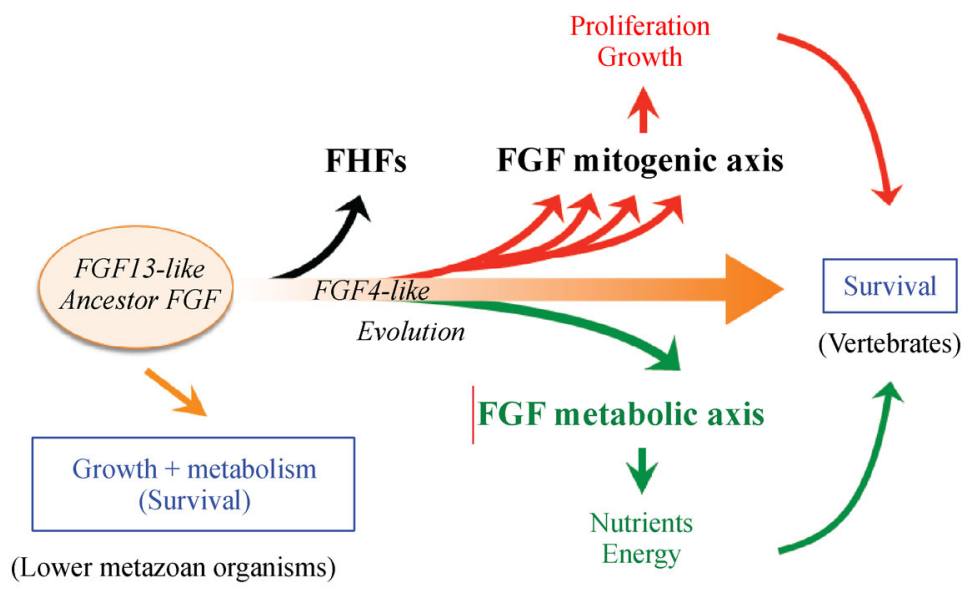

Fig. 1 Scheme of FGF metabolic axis evolution. The FGF family originates from a common FGF13-like ancestor molecule in early metazoans that bifurcates into the so-called intracrine FGF-homologous factor (FHF) subgroup (black arrow), including FGF11, 12, 13, and 14 (not shown), and FGF4-like molecule, which continues to bifurcate into two major functional subgroups with diverging structural and functional specifications. The socalled mitogenic FGF subgroups, including the FGF5, 8, 9, and 10 subfamilies (red arrows, Table 1), bind extracellular matrix heparan sulfate and drive autocrine/paracrine mitogenic signal axes to promote cell proliferation and population growth. By contrast, the endocrine FGF subgroup members (green arrow, Table 2), including FGF19, 21, and 23, drive metabolic signal axes that elicit broad-spectrum functions in regulating the metabolic homeostasis of bile acid, lipids, glucose, energy, and minerals without direct proliferation-promoting activity. However, both the FGF mitogenic and FGF metabolic axes are designed to promote cell and organismal survival in the vertebrates (orange arrows and blue-colored font). 
activities of the diverse mitogenic FGF axes have been a major focus of utilities as regenerative and repair agents in a range of medical settings [30-34]. In the past, we demonstrated the benefits of the application of mitogenic FGFs to tissue damage complications of diabetes mellitus, including diabetic cardiomyopathy, nephropathy, and neuropathy [35-37], as well as to wound healing and spinal cord injury repair [38-40]. On the other hand, the mitogenic FGF mediated cell miscommunications have also been on the menu for developing inhibitors to be used in cancer therapy $[29,41,42]$.

It should be pointed out that, although at a physiological level mitogenic FGFs are not evolutionarily designed to circulate and target distal tissues or organs for an endocrine effect, at pharmacological or supraphysiological levels, mitogenic FGFs exert certain regulatory activities beyond promoting cell proliferation and growth possibly due to their accumulation sufficiently to achieve an effect in distal metabolic tissues, where a cognate FGFR isotype is expressed. It was shown in the early 1990s that a bolus intravenous injection of FGF1 or 2 could target vascular endothelium to decrease arterial blood pressure [43]. FGF16 is expressed in classical brown fat depots during the later stages of embryonic development, and recombinant FGF16 is a mitogen for adipocytes [44]. Mice overexpressing FGF16 delivered by adeno-associated virus display dramatic weight loss and uncoupling protein-1 (UCP1) upregulation in inguinal white adipose tissue (WAT), which is a common site for emergent active brown adipose tissue (BAT). These effects are likely a combined result of reduced food and water intake and abnormal feces replete with lipid and bile acid due to the brain, liver, and intestinal actions of overexpressed FGF16 [45]. Mice deficient in FGF1 exhibit insignificant phenotypes under standard dietary conditions; however, under a chronic high-fat diet, these mice develop an aggressive diabetic phenotype coupled with aberrant adipose phenotypes, including multiple histopathologies in the adipose vasculature network, accentuated inflammatory response, aberrant adipocyte size distribution and expansion, and ectopic expression of pancreatic lipases [46]. In particular, we show by structure-based mutagenesis that FGF1 can be designed to have full metabolic activity of wild-type FGF1 but with reduced proliferative potential both in vitro and in vivo [47]. These studies underscore the important role of FGF1 in maintaining local adipose tissue homeostasis, which upon significant tissue perturbations impinges on the metabolic functions that subsequently affect the systemic metabolic state. Thus, the metabolic effects of several mitogenic FGF axes may be due to either a local function in maintaining cellular homeostasis that is closely associated with local metabolic state at a physiological concentration or an induced metabolic response to a supraphysiological concentration from circulation in the metabolic tissues or organs where FGFR resides. However, at pharmacological levels, few mitogenic FGFs may also be designed to elicit systemic metabolic effects.

\section{The metabolic FGF axis}

In contrast to mitogenic FGFs, the metabolic FGF subfamily contains only three members, namely, FGF19 (mouse FGF15), 21, and 23 [2,7,48-51]. However, the metabolic axes of these three FGFs regulate a wide range of metabolic pathways, resulting in tissue and organismal metabolic homeostasis of bile acids, lipid, glucose, energy, and minerals. Although the metabolic FGF axes do not overtly promote DNA synthesis, thereby leading to cell proliferation $[12,52,53]$, both metabolic and mitogenic FGF axes appear to enhance cell survival and promote an optimal state of homeostasis in the target tissues and organisms [7].

Based on current knowledge, the metabolic FGFs appear to originate from a common FGF13-like ancestor molecule as mitogenic FGFs and then bifurcate in early evolution through an FGF4-like molecule from all other mitogenic members by acquiring unique structural and mechanistic properties $[5,10,11,54]$, thereby leading to specific activities in modulating metabolic states in specific cell and tissue types [2]. Instead of acting locally, metabolic FGFs take a hormonal or endocrine route of action by traveling through circulation from the originating tissue to other peripheral tissues/organs. This endocrine action can be attributed to the loss of the structurally conserved HSbinding domain characteristic of the mitogenic FGFs [5]. Both the expression and target tissues of the metabolic FGFs are relatively limited to the metabolically active endocrine organs, such as liver, intestine, adipose tissue, pancreas, muscle, bone, kidney, heart, parathyroid, and specific neurons in specific regions of the central nervous system (CNS) $[55,56]$. In expression tissues, metabolic FGF genes are subject to direct transcriptional control by several major metabolite-responsive nuclear receptors, including farnesoid $\mathrm{X}$ receptor (FXR), peroxisome proliferator-activated receptor $\alpha$ (PPARA) and $\gamma$ (PPARG), carbohydrate-response element-binding protein (ChREBP), sterol regulatory element-binding protein-1c (SREBP1c), retinoic acid-related orphan receptor $\alpha$ (RORA), liver $X$ receptor $\beta$ (LXRB), vitamin $D$ receptor (VDR) [48-50,57-65], and stress-sensing transcription factors, such as ATF4 [66], depending on the location of specific nutrition/energy-sensing cells in specific tissues. In target tissues, the biological effects of the metabolic FGF axes are still mediated by FGFRs but in a different binary complex with a new transmembrane nonkinase accessory coreceptor, the $\alpha$-Klotho (KL) or $\beta$-KL (KLB) $[5,11,55,67]$ (Table 2), to which mitogenic FGFs do not bind. 


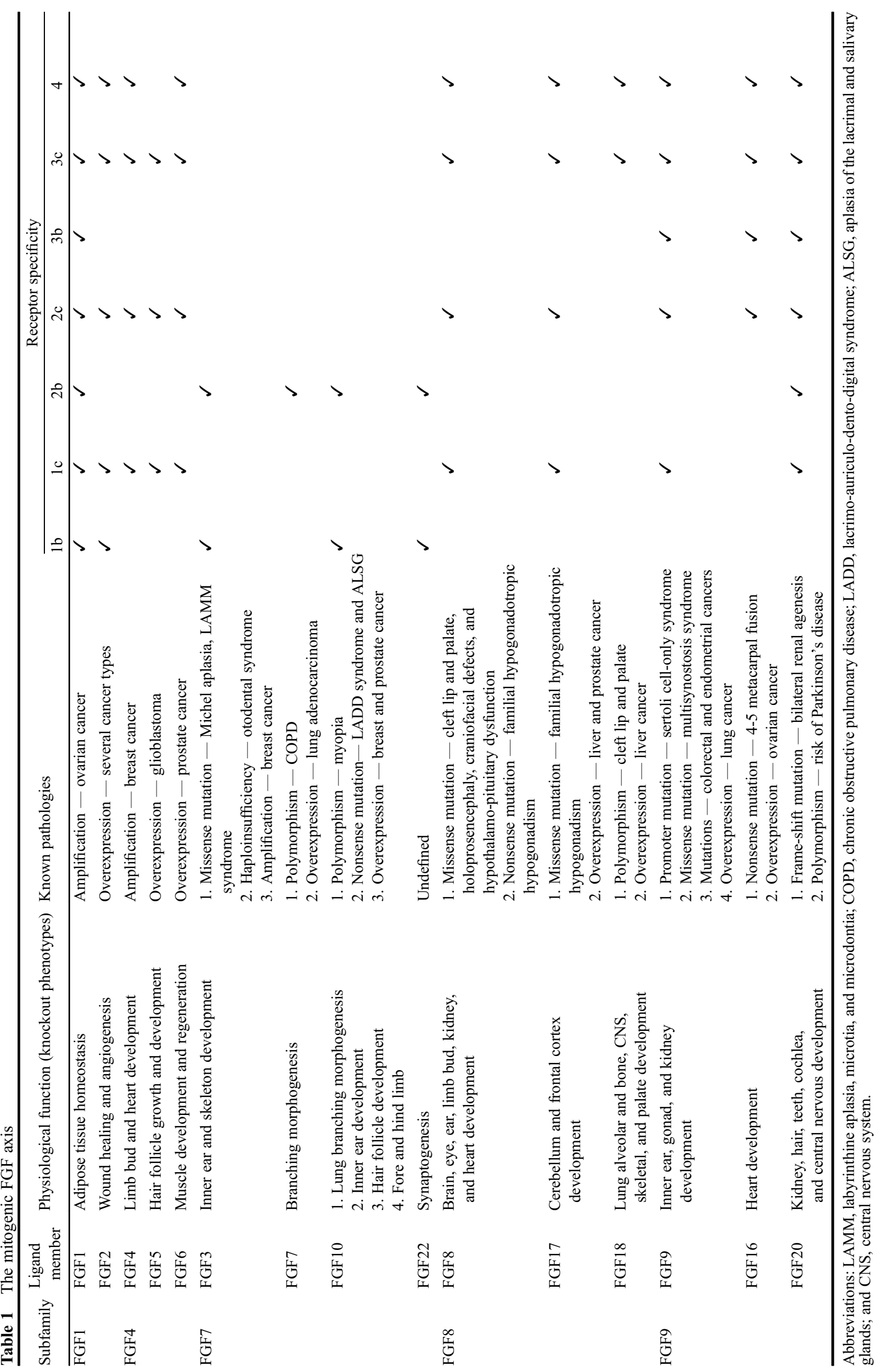


Structurally, metabolic FGFs coevolve with coreceptor $\mathrm{KL} / \mathrm{KLB}$ but also acquire new structural elements that direct specific contact interactions with KL/KLB and FGFRs, thereby leading to a tethered basic triad complex and subsequent activation of intracellular kinase domains of FGFRs $[5,11]$. The C-terminus of the metabolic FGFs mimics the interaction mode of a sugar chain that docks into the pseudo-glycolytic pocket of $\mathrm{KL} / \mathrm{KLB}$ while interacting with FGFR ectodomains through the domains that are conserved across the FGF family [5,68]. Meanwhile, the interacting KL/KLB protrudes an "arm" from the membrane-proximal glycosidase domain griping onto the FGFR ectodomain.

Although the FGFRs, in particular FGFR1, are broadly expressed, the highly restricted expression of KL/KLB and metabolic FGFs, and the new structural elements and mutual interaction modes, set the tone for tissue-specific functions of the metabolic FGF axes (Table 2). The different intracellular molecular constituents in different cells types, which are tailored to perform specific biological functions, may be also an important limiting factor. For instance, the adult adipocytes are not poised in a normal context to increase population by direct proliferation due to the loss of several key proliferation-controlling pathways, thereby partly accounting for the inability of the activated FGFR1 by FGF21 to promote adipocyte proliferation. Overall, metabolic FGFs appear to be inducible stress factors in response to organismal metabolic perturbations $[7,69]$ and signal distal peripheral tissues through the FGFR-KL/KLB complex to control due metabolic pathways. In this sense, the metabolic FGF acts as a key to ignite the FGF-FGFR-KLB/KLB triad complex, which functions similarly as an engine with an axis to drive effects in a tissue-specific manner, thereby leading to beneficial effects that offset the initial adverse metabolic changes and prevent metaflammation and tissue damage not only in the FGF-producing tissues but also systemically [2,7] (Table 2). Consequently, both the analogs of endocrine FGFs and the agonists of FGF-KL/ KLB have been actively pursued clinically for the prevention and treatment of a wide range of metabolic diseases and comorbidities [2,70-75].

Table 2 The metabolic FGF axis.

\begin{tabular}{|c|c|c|c|c|c|c|c|c|c|c|c|c|}
\hline \multirow{2}{*}{ Subfamily } & \multirow{2}{*}{$\begin{array}{l}\text { Members } \\
\text { of ligands }\end{array}$} & \multirow{2}{*}{$\begin{array}{l}\text { Physiological function } \\
\text { (knockout phenotypes) }\end{array}$} & \multirow{2}{*}{ Known pathologies } & \multicolumn{9}{|c|}{ Receptor specificity } \\
\hline & & & & $\overline{1 b}$ & $1 \mathrm{c}$ & $2 b$ & $2 \mathrm{c}$ & $3 b$ & $3 \mathrm{c}$ & 4 & $\mathrm{KL}$ & KLB \\
\hline \multirow[t]{3}{*}{$\overline{\text { FGF19 }}$} & FGF19 & $\begin{array}{l}\text { 1. Bile acid metabolism } \\
\text { 2. Gall bladder filling } \\
\text { 3. Lipid and energy } \\
\text { metabolism }\end{array}$ & $\begin{array}{l}\text { 1. Bile acid diarrhea, IBD } \\
\text { 2. Cholestasis } \\
\text { 3. Overexpression } \\
\text { - liver cancer }\end{array}$ & & $\checkmark$ & & $\sqrt{ }$ & & $\checkmark$ & $\checkmark$ & & $\checkmark$ \\
\hline & FGF21 & $\begin{array}{l}\text { 1. Lipid metabolism } \\
\text { - lipolysis, fatty acid } \\
\text { oxidation, lipogenesis } \\
\text { 2. Energy metabolism } \\
\text { - uncoupling } \\
\text { thermogenesis } \\
\text { 3. Macronutrient } \\
\text { preference } \\
\text { 4. Starvation response } \\
\text { and associated } \\
\text { physiology } \\
\text { 5. Insulin sensitivity and } \\
\text { glucose homeostasis }\end{array}$ & $\begin{array}{l}\text { 1. Obesity } \\
\text { 2. Diabetes } \\
\text { 3. NAFLD } \\
\text { 4. Hyperlipidemia } \\
\text { 5. Metabolic syndrome } \\
\text { 6. Pancreatitis }\end{array}$ & & $\checkmark$ & & & & $\checkmark$ & & & $\checkmark$ \\
\hline & FGF23 & $\begin{array}{l}\text { Phosphate, calcium, } \\
\text { sodium, and vitamin D } \\
\text { homeostasis }\end{array}$ & $\begin{array}{l}\text { 1. Activation mutation } \\
\text { - autosomal dominant } \\
\text { hypophosphatemic rickets } \\
\text { and tumor-induced } \\
\text { osteomalacia } \\
\text { 2. Inactivation mutation } \\
\text { - familial tumoral } \\
\text { calcinosis } \\
\text { 3. Increase } \\
\text { - X-linked dominant } \\
\text { hypophosphatemia, CKD } \\
\text { 4. Decrease } \\
\text { - GALNT3-related } \\
\text { familial tumoral calcinosis }\end{array}$ & & $\checkmark$ & & & & $\checkmark$ & $\checkmark$ & $\checkmark$ & \\
\hline
\end{tabular}

Abbreviations: IBD, inflammatory bowel disease; NAFLD, nonalcoholic fatty liver disease; CKD, chronic kidney disease; and GALNT3, polypeptide Nacetylgalactosaminyltransferase 3 . 


\section{FGF19 metabolic axis}

FGF19 is the prime controller of diurnal bile acid flux, and the FGF19-driven metabolic axis is a temporal interorgan crosstalk from the ileum to the liver in response to the increase in the postprandial serum and transintestinal flux of bile acids [2,49] (Fig. 2). This axis serves to control the enterohepatic and systemic levels of bile acids negatively, which facilitate the uptake and absorption of dietary lipids after a meal but are toxic as biodetergent if the flux is prolonged at increased levels. The ileal initiation of the FGF19 signal is under the transcriptional control of FXR, which is stimulated by the reabsorbed enterocyte bile acids as a natural ligand that is originally released from gallbladder and mixed with food traveling down from the duodenum to jejunum and ileum. This enterocytederived FGF19 activates the remote FGFR4-KLB complex [67] residing across the membrane of hepatocytes in the liver, resulting in a major feedback termination of the transcription of the rate-limiting enzymes Cyp7A1 and Cyp8b1 in the bile acid biosynthesis pathways $[49,76]$.
Therefore, the FGF19 axis triggers the shut-off of hepatic biosynthesis of new bile acids from cholesterol and the refilling of gallbladder approximately $2 \mathrm{~h}$ after the peak of serum bile acids is reached.

In experimental animals, FGF19 overexpression or administration elicits other metabolic effects [77,78]. Excessive FGF19 promotes lipolysis, metabolic rate, and energy expenditure and reduces body weight, serum glucose, and lipids. The FGFR1-KLB complex on adipose tissues, including WAT and BAT, was suggested in a large part to mediate these metabolic effects [79] (Fig. 2). However, the direct metabolic roles of bile acid fluctuation and bile acid-activated FXR and TGR5 cannot be excluded.

Although there is no evidence for any genetic mutation of FGF19 gene that may be involved in human metabolic diseases, its reduced synthesis and blood levels are suggestive of a causative factor of chronic bile acid diarrhea [80,81] and certain metabolic disorders, such as metabolic syndrome, nonalcoholic fatty liver disease (NAFLD), and insulin resistance. Experimentally, the

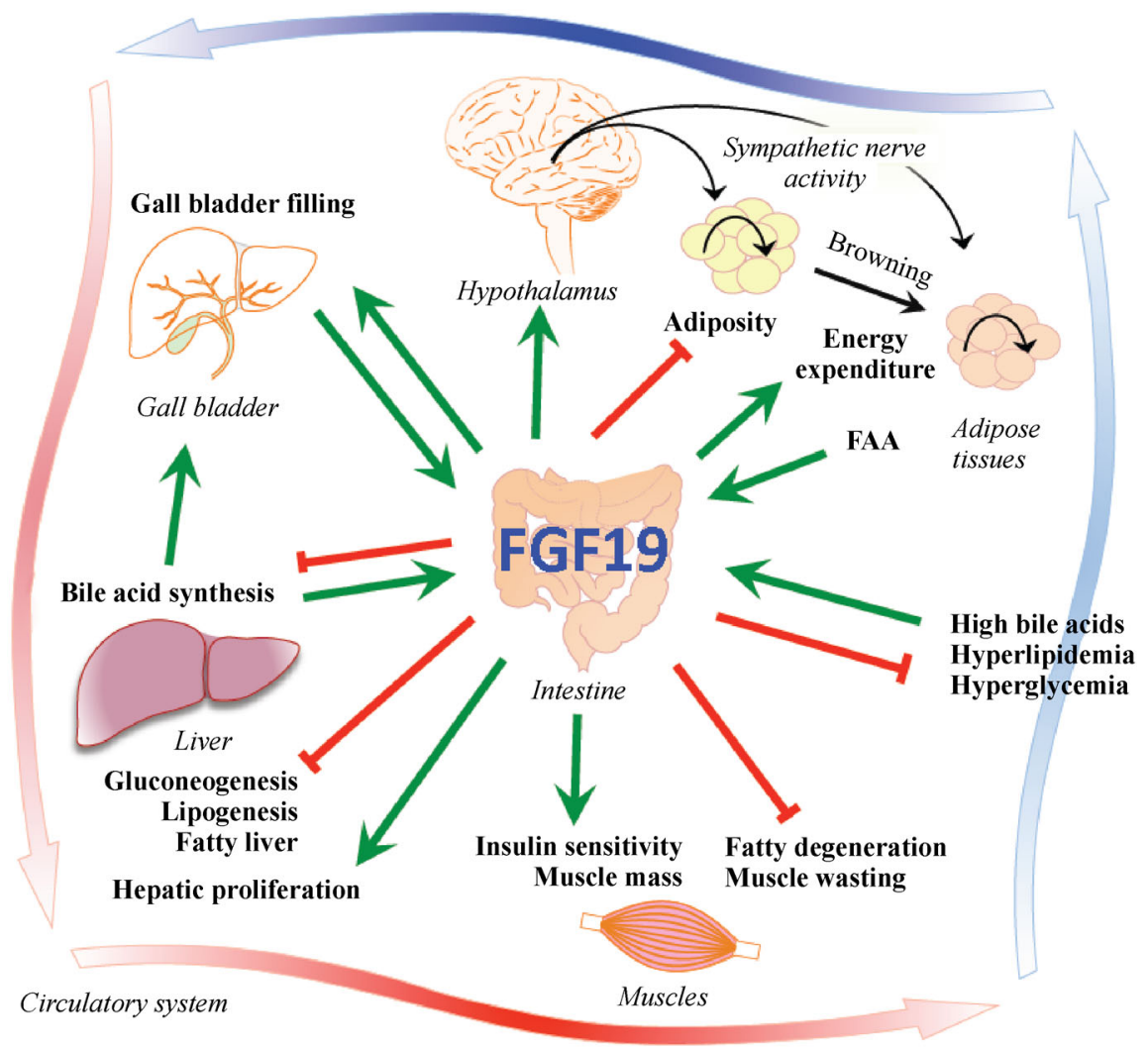

Fig. 2 FGF19 metabolic axis. The major FGF19 metabolic axis drives a temporal interorgan crosstalk from the ileum to the liver in response to the increase in postprandial serum and transintestinal flux of bile acids to discontinue the biosynthesis of new bile acids after sufficient food digestion, thereby preventing the prolonged exposure of tissues to potential bile acid toxicity. Pharmacological FGF19 may also initiate multiple signal axes to drive effects on multiple tissues/organs, such as promoting (green arrow) energy expenditure in white and brown adipose tissues, increasing muscle mass and insulin sensitivity, and preventing (red long-tailed " $T$ " sign) systemic hyperglycemia and hyperlipidemia. FAA: free fatty acids. 
neutralization of FGF19 by specific anti-FGF19 antibodies causes severe diarrhea in monkeys accompanied by the increases in bile acid synthesis, serum and fecal total bile acids, specific bile acid transporters, and liver toxicity [82]. In obese patients who undergo Roux-en-Y gastric bypass bariatric surgery, FGF19 increases to normal values, which at least partially underlie the benefits of this approach [83]. On the other hand, high FGF19 expression levels are found in the livers of patients with extrahepatic cholestasis $[84,85]$, suggesting FGF19 as a therapeutic target for this disease.

Recently, the FGF19 axis was shown to elicit hypertrophic and protective effects on the skeletal muscle presumably through a KLB-FGFR4-dependent mechanism by increasing myofiber size in the soleus, muscle mass, and grip strength [86]. Pharmacological FGF19 ameliorates skeletal muscle atrophy and prevents muscle wasting in mice with glucocorticoid treatment, obesity, or sarcopenia. These results highlight a potential treatment strategy for muscle wasting induced by glucocorticoid treatment, obesity, aging, and cachexia. However, whether the same treatment will have a similar adverse effect on the liver still has to be determined because muscle-specific transgenic mice developed prominent hepatocellular carcinoma (HCC) [87].

Despite the tumorigenic concern, the FGF19 analog NGM282 was tested in patients with nonalcoholic steatohepatitis (NASH). It markedly reduced liver fat content but with significant side effects [70]. In a phase 2 trial in patients with type 2 diabetes and chronic idiopathic constipation, NGM282 significantly improved bowel function by accelerating gastric emptying and colonic transit [81]. Furthermore, NGM282 was further tested in mouse models and human patients with cholestasis and primary biliary cholangitis, showing efficacy in significantly reducing bile acid levels and improving hepatic inflammatory injury and fibrosis $[84,88,89]$.

\section{FGF21 metabolic axis}

FGF21 is a prime lipid catabolic factor that regulates energy balance. However, the physiological roles and pharmacological effects of FGF21-driven metabolic axes are multifaceted $[2,7,90]$ (Fig. 3). FGF21 was discovered as a driver of glucose uptake in adipocytes and a PPAR $\alpha-$ dependent hepatic starvation hormone [48,50,51]. In mice, FGF21 levels are induced when calories are restricted or when glucose is low to allow fats to be burned for energy supply. The increasing levels of FGF21 drive diverse aspects of the adaptive starvation response, including stimulation of hepatic fatty acid oxidative for ketone body production during prolonged fasting and starvation. Whether this action of FGF21 is autocrine/paracrine in the liver or endocrine in adipose tissues through adipose lipolysis and fatty acid oxidation is a matter of debate. The liver is a major contributor to the circulating FGF21 levels, which is associated with hepatic fat content and adiposity but inversely associated with serum glucose levels [9193]. The hepatic expression of FGF21 is responsive not only to starvation but also to a broad spectrum of cellular, metabolic, or pathological changes in the liver as well as systemic metabolic perturbations [7,69,94]. As FGF21 is incapable of activating FGFR4-KLB complex [67], which is predominant in the liver that expresses FGFR1-KLB with lower levels, hepatic FGF21 acts mainly as an endocrine factor to drive the metabolic pathways in peripheral tissues, including WAT, BAT, muscle, heart, kidney, and CNS that express high levels of FGFR1/2/3$\mathrm{KLB}$, leading to the correction of metabolic derangements and amelioration of metaflammation and stress damage (Fig. 3) [7,94].

Although the liver is unlikely a major direct target of FGF21, the effects of FGF21 on the liver are prominent. In addition to its role as a regulator of integrated hepatic metabolism in multiple aspects [48,50,95-98], including fatty acid oxidation, ketogenesis, gluconeogenesis, and macronutrient preference, FGF21 counteracts hepatic pathologies in response to a number of nutritional and chemical insults, including ketogenic diet, high fat diet, high fructose diet, methionine and choline deficient diet, ethanol-supplemented diet, and diethylnitrosamine [99103]. Under a chronic obesogenic diet, FGF21-deficient mice developed a spectrum of progressive fatty liver disease, including simple hepatosteatosis to NASH, fibrosis, and HCC, which is the most lethal complication of this disorder. These findings highlight the role of FGF21 metabolic axis as a defensive barrier for the deleterious stress damage caused by metabolic disorders in the liver [104]. Current clinical trials with FGF21 analogs show promising efficacy against NAFLD, NASH, and fibrosis without noticeable adverse side effects [73].

Acting on WAT and BAT, the FGF21 axis drives an array of catabolic effects, including insulin-independent glucose uptake, lipid droplet expansion inhibition, lipolysis, fatty acid oxidation, white adipocyte beigeing, and thermogenic dissipation of energy $[79,105,106]$. This route of action has been proposed as a major endocrine axis of FGF21 for insulin sensitization; lowering of systemic glucose, triacylglycerol, and LDL; fighting against obesity, diabetes, fatty liver diseases, hyperlipidemia, and associated comorbidities; and achieving metabolic health $[2,73$, 74,107]. Some of these effects are likely mediated by adipokines, such as CCL11 and adiponectin, as shown in mice $[108,109]$. In cold-induced nonshivering thermogenesis or exercise stress condition, BAT also becomes a source of endocrine FGF2 1 in a $\beta$-adrenergic- and cAMPdependent manner, which in turn facilitates mitochondrial genesis, oxidative capacity, uncoupling, and heat generation, leading to adaptation to cold conditions and core body temperature maintenance [110-112]. 


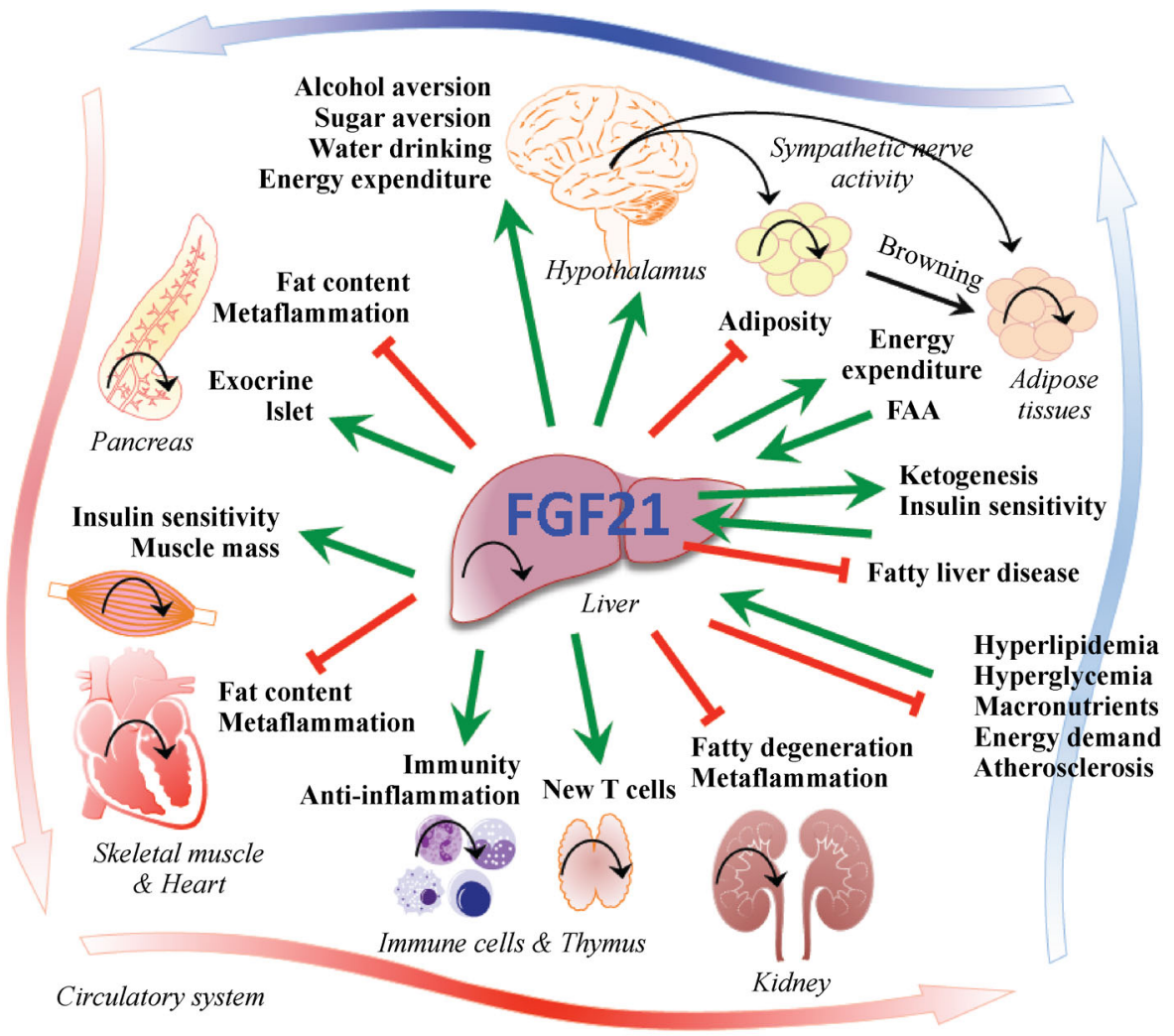

Fig. 3 FGF21 metabolic axis. The liver is the major organ of origin of endocrine FGF21 in response to a broad spectrum of stress conditions. The hepatic and pharmacological FGF21 drive multiple signal axes in multiple tissues/organs, resulting in multifaceted beneficiary metabolic effects, including promoting (green arrow) glucose, lipid, and energy homeostasis; offsetting metabolic derangements; and preventing (red long-tailed "T" sign) metaflammation, inflammatory tissue damage, and tissue-specific pathogenesis, including obesity, type 2 diabetes, fatty liver disease, metabolic syndrome, and associated comorbidities. FAA: free fatty acids. Black semicircular arrows indicate possibility of paracrine mode of FGF21 within local tissue environment.

In line with the beneficial effects of FGF21 on maintaining metabolic homeostasis during diverse adverse conditions, pharmacological FGF21 markedly extends the lifespan of mice by blunting the growth hormone/insulinlike growth factor-1 signaling pathway in the liver without reducing food intake or affecting longevity-associated markers of $\mathrm{NAD}^{+}$metabolism, AMP kinase, and mTOR signaling pathways [113]. The thymus functions in producing new $\mathrm{T}$ cells for the immune system, but with age, it becomes fatty and loses the ability to produce a sufficient amount of new $\mathrm{T}$ cells, which is an important cause of increased risks of infections, obesity, diabetes, and certain cancer types, leading to reduced lifespan in the elderly people. The FGF21 level in thymic epithelial cells is several folds higher than that in the liver. The high level of FGF21 is proposed to protect thymus from the agerelated fatty degeneration and to increase the production of new $\mathrm{T}$ cells to bolster immune function, thereby lowering the incidence of diseases and promoting longevity [114].

The acinar cell compartment in the pancreas expresses the highest levels of FGF21 constitutively among tissues, but contributes little to the circulation [56,115]. Acinar cells appear to be both the dominant source and target (via FGFR1-KLB complex) of pancreatic FGF21. The high levels of FGF21 is proposed to act as an exocrine pancreas secretagogue to stimulate pancreatic digestive enzyme secretion and pancreatic juice flow to the intestine, thereby relieving potential self-digestion caused proteostasis stress and protecting pancreas from pancreatitis, including but not limited to those caused by high-fat diet, pancreatic toxins, and alcoholism [116]. Although islets express significantly lower amounts of FGF21, acinar cell derived or endocrine FGF21 helps protect against fatty pancreas, high-fat diet induced islet hyperplasia, and inflammatory damage [117-119]. Demyelination in the CNS can cause severe neurological deficits, such as multiple sclerosis and neurological dysfunction. Pancreatic FGF21 acts on oligodendrocyte precursor cells to promote the remyelination process, leading to better recovery of neurological functions in mice [120]. 
Exposure to alcohol or sugar induces hepatic FGF21 through ChREBP, which then acts on the hypothalamus reward pathway to suppress the desire for sugar and alcohol in favor of drinking water in mice depending on the $\beta$-adrenergic circuit $[97,98,121,122]$. This finding may represent a new hydration pathway that is independent of the classical renin-angiotensin-aldosterone thirsty pathway in the kidney in response to nutritional stress, suggesting a previously underappreciated association of water intake to metabolism through the FGF21 metabolic axis. A human rs838133 allele in FGF21 is associated with higher alcohol and sugar intake and higher blood pressure and waist-hip ratio, with lower total body-fat percentage [123]. Comparison of the genomes of more than 105000 light and heavy social drinkers also identifies a variation in the rs 11940694 locus of the $K L B$ gene in association with the aversion for alcohol [124]. Neuronal cell stress reaction, such as those caused by disturbances in the mitochondria and endoplasmic reticulum (ER), is an important factor in the development of neurodegenerative diseases. Studies found that the integrated stress response induces neuronal FGF21, which presumably serves to attenuate stress and neural damage [125].

In addition to the liver, pancreas, and adipose tissues, cardiac muscle produces FGF21 in response to cardiac stress, cardio exercise, and endurance training [126,127], which then speeds up glucose uptake, lipid catabolism, and energy metabolism, and protects against cardiovascular stress damage, apoptosis, and heart dysfunctions, such as cardiac hypertrophy, myopathy, steatosis, ischemic infarction, and atherosclerosis [128-132]. Through a multiorgan crosstalk, hepatic FGF21 drives the expression of angiotensin-converting enzyme 2 in adipocytes and renal cells, which hydrolyzes angiotensin II to active vasodilator angiotensin-(1-7) in the renin-angiotensin system, thereby alleviating angiotensin II-associated hypertension and reversing vascular damage [133]. Skeletal muscle under the bouts of exercise or stress, such as mitochondrial myopathies, also induces FGF21 expression [134-136]. In turn, FGF21 acts on muscle and adipose tissue to reduce lipid load by increasing lipolysis, fatty acid utilization, energy expenditure, and insulin sensitivity, thereby preventing diet-induced obesity and insulin resistance [137-140].

Hepatic FGF21 acts on the paraventricular nucleus in the hypothalamus to drive the release of corticotropin-releasing factor, which then stimulates the involuntary sympathetic nerve activity. This leads to the activation of brown adipose tissue by upregulaing UCP1 and increases of glucose uptake, lipolysis, mitochondrial oxidation of fatty acids and glucose, body heat generation, and weight loss $[141,142]$. The increase in corticotropin-releasing factor levels may also stimulate the pituitary gland to release adrenocorticotrophic hormone and subsequent corticoster- one production in adrenal cortex, leading to increased hepatic gluconeogenesis during prolonged fasting to prevent hypoglycemia [143]. Hepatic FGF21 acts on the suprachiasmatic nucleus ( $\mathrm{SCN}$ ) in the hypothalamus to suppress the vasopressin-kisspeptin and gonadotropinreleasing hormone signaling cascade, which then inhibit the proestrus surge in luteinizing hormone from anterior pituitary gland, thereby contributing to female infertility in response to nutritional challenge, such as prolonged starvation [144]. The SCN action of FGF21 may also alter circadian behavior [145]. By increasing neuropeptide $\mathrm{Y}$ levels and Y1 receptor activation, the hypothalamus action of FGF21 may decrease locomotive activity, metabolic rate, and body temperature, leading to torpor under nutrition limitation [146]. FGF21 may also act on the hippocampus to decrease reactive oxygen species and inflammatory damage, thus decreasing brain cell damage and improving cognition $[147,148]$.

The endocrine FGF21 axes as well as the paracrine FGF21 axes within the local tissue compartments have been shown in many tissues and organs to counteract stress response and attenuate stress-ensued inflammation and inflammatory damage $[7,104,117]$. Therefore, FGF21 is not only a stress-responsive or -induced factor but also an anti-stress and anti-inflammatory factor. The stress-offsetting effects, in particular the anti-inflammatory activities, can be attributed to the metabolic effects of FGF21 axes that prevent fatty degeneration, gluco-lipotoxicity, oxidative and ER stress, and inflammatory and immune cell infiltration. These metabolic activities may be mediated in part through efficient and durable systemic and local glycemic and lipidemic control, improvement of insulin sensitivity, and promotion of lipid catabolism (lipolysis and fatty acid oxidation), adipose beigeing, and futile energy expenditure in adipose tissues, local adipocytes, and brain in both UCP1-dependent and adrenergic sympathetic nervous system-dependent mechanisms $[79,105,106,141,149,150]$. As a result, FGF21 effectively reverses hepatic steatosis in obese mice and clinical obese patients $[73,105,151]$. Furthermore, the pharmacological FGF21 analogs and FGFR1-KLB agonists have been shown to directly improve the spectrum of adverse components of metabolic syndrome, including central obesity, insulin resistance, fasting hyperglycemia, dyslipidemia, systemic hypertension, and fatty liver, which are the major risk factors for cardiovascular disease (CVD), type 2 diabetes mellitus, chronic kidney disease (CKD), and all-cause mortality $[2,7,73,74,107]$. The FGF2 1 axes suppress atherosclerotic plaque by reducing hypercholesterolemia, oxidative stress, and smooth muscle cell proliferation via adiponectin-dependent and adiponectinindependent mechanisms [129]. FGF21-deficient mice developed significant islet hyperplasia and periductal lymphocytic inflammation upon chronic challenge of an 
obesogenic high-fat diet, indicating a protective role of FGF21 in compensatory islet hyperplasia and pancreatic inflammation associated with obesity $[117,152]$. FGF21 directly suppresses triglyceride levels and lipid accumulation in kidney tissues, thereby reducing lipotoxicity, oxidative stress, inflammation, glomerular abnormalities, fibrotic renal injury in diabetic nephropathy, while deficiency of FGF21 aggravates these conditions $[153,154]$, indicating a defensive role of FGF21 against kidney pathogenesis associated with obesity and diabetes.

The anti-stress and anti-inflammatory effects of FGF21 may be also attributable to its direct action on nonmetabolic cells and non-metabolic activities. FGF21 directly inhibits cardiomyocyte apoptosis, oxidative stress, myocardial injury, thereby reducing the risk of pathological cardiac remodeling and dysfunction, cardiac hypertrophy, myocardial ischemia, and heart failure in ischemic heart tissue and diabetic cardiomyopathy $[130,155]$. FGF21 protects the pancreas from caerulein- and Larginine-induced pancreatitis, acinar cell injury, and fibrosis in mice $[118,119,156]$. FGF21 acts directly on renal mesangial cells to reduce glucose reabsorption and prevent hyperglycemia-induced fibrogenesis in $d b / d b$ mice $[157,158]$. Interestingly, recent evidence supports that FGF21 can directly act on inflammatory and immune cells to attenuate inflammation and inflammatory damage. FGF21 activates THP-1-derived macrophages to promote cholesterol efflux, oxidized low-density lipoprotein (oxLDL) uptake, and foam cell formation and inhibits macrophage inflammatory capacity through the Nrf2 pathway $[156,159,160]$. Adipose tissue is an endocrine organ and plays an active role in the inflammation in obesity that can favor CVD and CKD progression by inducing a chronic and low-grade inflammation via secreted proinflammatory adipokines and cytokines. Studies in diet-induced obesity and pancreatitis models indicate that FGF21 promotes anti-inflammatory macrophage polarization in adipose depots and pancreas, WAT browning, and insulin sensitivity, thereby effectively preventing adipose tissues from adapting proinflammatory profiles and the pancreas from inflammatory fibrosis $[109,156,159,161]$. Interestingly, FGF21 was found highly expressed in neutrophils and monocytes among circulating leukocytes and stimulates phagocytosis, glucose uptake, and reactive oxygen species production in a NADPH oxidase-dependent manner in the neutrophil-like HL-60 and monocytic THP-1 cells [162-164]. In the type II collagen-induced arthritis mouse model, FGF21 acts on the spleen to reduce inflammatory IL-17, TNF- $\alpha$, IL-1 $\beta$, IL-6, IL-8, and MMP3 and the number of splenic TH17 cells, thereby alleviating arthritis severity [165]. These studies highlight the potential mediator role of FGF21 in innate immunity and inflammatory disorders. The direct impact of FGF21 on the function of inflammatory and immune cells and associated health consequences is yet to be validated.

\section{FGF23 metabolic axis}

FGF23 is a key hormonal regulator of phosphate, vitamin $\mathrm{D}$, and calcium metabolism, and its metabolic axes drive a complex interorgan crosstalk network for bone health and systemic mineral balance (Fig. 4) [2,61,166-168]. Osteoblastic cells in osseous tissue are the major source of FGF23 in response to elevated calcitriol, increased phosphate and calcium burdens, increased parathyroid hormone, iron and magnesium loss, and active bone remodeling in a vitamin $\mathrm{D}$ receptor dependent mechanism. Acting on kidneys that express the FGFR1-KL complex, the FGF23 signal axis represses the expression of NPT2a and NPT2c, the sodium-phosphate cotransporters in the proximal tubule, thereby decreasing reabsorption and increasing secretion of phosphate in renal brush border membrane vesicles. Another important function of this bone to kidney FGF23 signal axis is suppressing the expression of 25-hydroxyvitamin D3-1- $\alpha$-hydroxylase and stimulating the expression of 1,25-dihydroxyvitamin $\mathrm{D}(3)$ 24-hydroxylase, thereby inhibiting the production of active calcitriol in renal proximal tubules, which subsequently inhibits the expression of NPT $2 b$ and phosphate absorption in the apical brush border of small intestine. The bone FGF23 acts on the basolateral FGFR1-KL complex in the renal distal tubules to increase the intracellular transport of fully glycosylated TRPV5 from the Golgi apparatus to the plasma membrane, thereby stimulating calcium reabsorption in distal renal tubules and preventing calcium loss [169]. These FGF23-associated axes also directly increase the membrane abundance of the $\mathrm{Na}^{+}: \mathrm{Cl}^{-}$cotransporter NCC in distal renal tubules, and thus, increase sodium reabsorption, plasma volume, and blood pressure [170]. This change may be a new cause of high blood pressure and heart disease under the modern processed phosphaterich foods.

Bone FGF23 also acts on the parathyroid gland to inhibit the production and secretion of parathyroid hormone (Fig. 4) [171], which then reduces serum calcium through its effects on the bone, kidney, and intestine. High serum FGF23 levels in patients with CKD decrease calcitriol, thereby contributing to the development of secondary hyperparathyroidism, which has a crucial role in increasing the levels of FGF23 because the parathyroid hormone stimulates FGF23 expression.

Recent studies revealed the potential roles of the FGF23 axis in suppressing erythropoiesis in bone marrow. Erythroid progenitor cells highly express FGF23 and FGFR-KL, suggesting that they are both a source and a target of FGF23. The loss of FGF23 or injection of an FGF23-blocking peptide in mice results in increased erythropoiesis, reduced erythroid cell apoptosis, and increased renal and bone marrow erythropoietin (EPO) expression with increased circulating EPO levels. On the other hand, the increased EPO or acute blood loss increases 


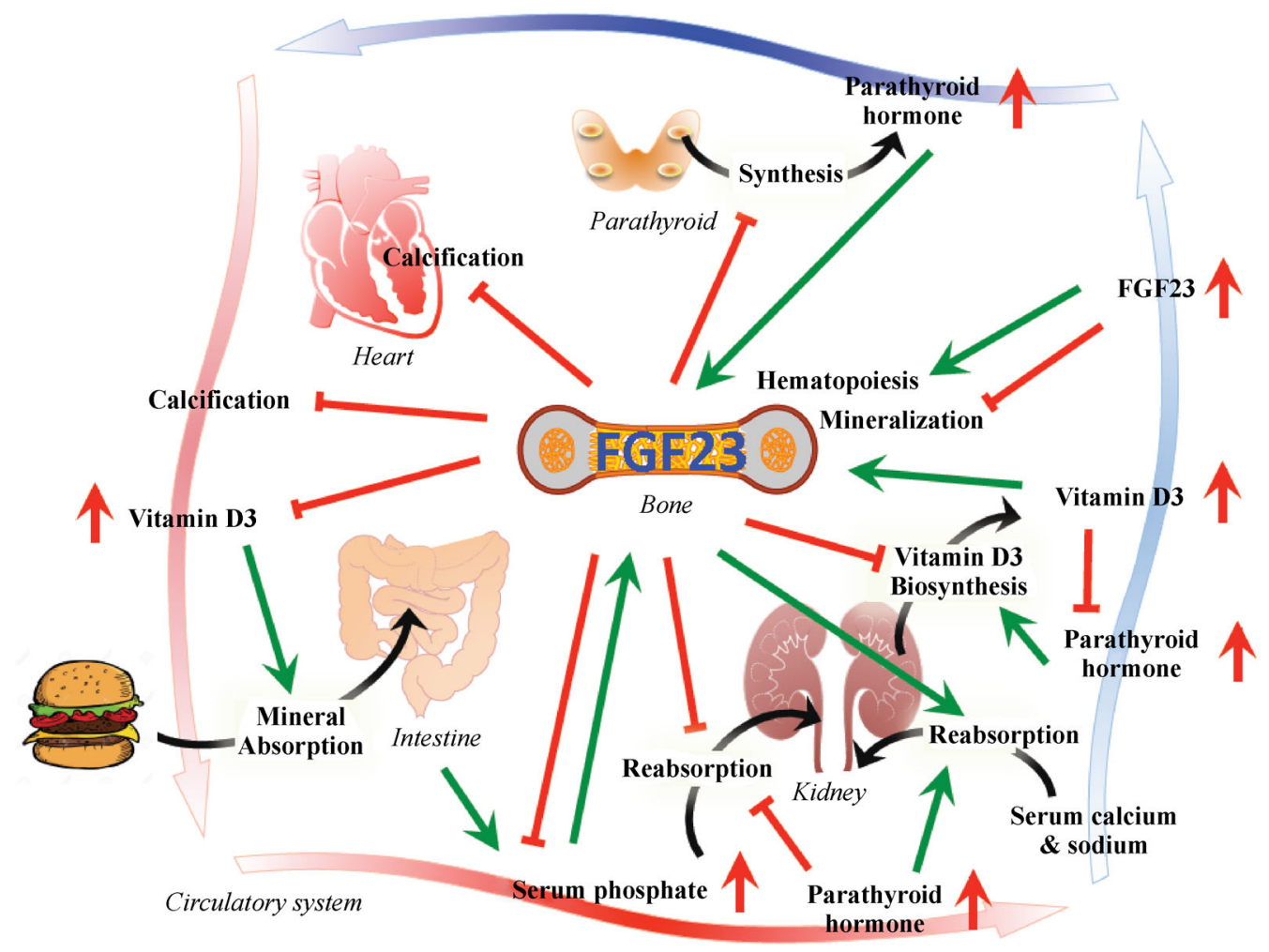

Fig. 4 FGF23 metabolic axis. The bone-derived FGF23 drives signal axes to promote (green arrows) the metabolic homeostasis of phosphate, vitamin $\mathrm{D}$, and calcium through a complex interorgan crosstalk network for bone health and systemic mineral balance. The bone to the kidney axis of FGF23 is central to the metabolic roles of FGF23, which inhibits (red long-tailed "T" sign) the reabsorption of phosphate and the production of active calcitriol in renal proximal tubules while increasing the calcium and sodium reabsorption in renal distal tubules. The bone to parathyroid axis of FGF23 inhibits the production and secretion of parathyroid hormone that also plays critical roles in mineral and vitamin D balance.

FGF23 expression in the bone marrow with a concomitant increase in serum FGF23 [172,173]. A recent study suggests that FGF23 is involved in the association between functional iron deficiency, increased EPO levels, and death. The further elucidation of the role of the EPOFGF23 signaling axis in hereditary anemia and chronic hemolytic diseases, CKD, and mineralization disorders will add to the understanding of the pathophysiology of these diseases and life expectancy and will inform new treatment strategies for the diseases.

Current evidence indicates that FGF23 is more structurally unique than FGF19 and 21 [5]. FGF23 contains a conserved furin-sensitive ${ }^{176}$ RHTR ${ }^{179}$ cleavage site near the C-terminus, which inactivates the intact FGF23 upon cleavage, leading to signal attenuation. The biological importance of this activity control mechanism is demonstrated by point mutations (e.g., R176Q, R179Q, and $\mathrm{R} 179 \mathrm{~W})$ of this site, which results in cleavage-resistant FGF23 and increased circulating levels of active FGF23, in autosomal dominant hypophosphatemic and vitamin Ddeficient rickets characterized by renal phosphate wasting, hypophosphatemia, rickets, osteomalacia, leg deformities, short stature, bone pain, and dental abscesses [168,174, 175]. FGF23 levels are increased and may play important roles in other hereditable and acquired phosphate wasting disorders, including X-linked dominant hypophosphatemic rickets, autosomal recessive hypophosphatemic rickets, hypophosphatemic rickets associated with McCuneAlbright syndrome/fibrous dysplasia of bone, and linear sebaceous nevus syndrome [176,177]. The increased FGF23 levels are also found in acquired phosphate wasting disorders in some tumor types, such as the benign mesenchymal neoplasm phosphaturic mesenchymal tumor, causing tumor-induced osteomalacia, a paraneoplastic syndrome [168].

During post-translational modification, FGF23 is glycosylated at Thr-178 in the cleavage site by GalNT3, which facilitates its secretion and protects the protein from being broken down, suggesting a novel posttranslational regulatory model of FGF23 involving competing O-glycosylation and proteolytic processing to determine the level of secreted active FGF23 [178]. The importance of this glycosylation modification is demonstrated by inactivating GalNT3 mutations that render FGF23 susceptible to 
proteolysis $[179,180]$, thereby reducing circulating intact hormone levels and leading to autosomal recessive familial tumoral calcinosis that manifests with hyperphosphatemic and massive calcium deposits in the skin and subcutaneous tissues throughout the body. Consistently, at least seven mutations in the conserved backbone of FGF23, such as S71G, M96T, S129F, and F157L, destabilize the tertiary structure and render it susceptible to degradation, thereby resulting in autosomal recessive familial tumoral calcinosis with hyperphosphatemia [2,5,181-184].

Patients with CKD have increased serum levels of phosphate as well as FGF23, which lead to increased uptake of calcium by the kidneys, resulting in vascular calcification. This explains the CVD complications, such as cardiac hypertrophy and congestive heart failure, in patients with CKD $[185,186]$. The inhibition of FGF23 or its axis could be a strategy to bring CVD and vascular calcification under control. The FGF23 level in patients with CKD can even indicate their life expectancy. The dysregulation of calcium levels can have an array of serious health consequences. Chronic hypocalcemia can potentially lead to heart failure, nervous system and muscle disorders, and encephalopathy, while hypercalcemia can increase the risk of kidney stones, cause muscle weakness, and worsen psychological issues, such as dementia and depression. This may explain some current observations that people with high serum FGF23 can be at risk of dementia, and that mice lacking FGF23 exhibit defective learning and memory problems similar to those seen in KL-deficient mice $[187,188]$.

\section{Conclusions and future perspectives}

The three members of the metabolic FGFs, including FGF19, 21, and 23, share a conserved core structure of $\beta$ trefoil fold but diverge in functions from other mitogenic members of the FGF family during evolution (Fig. 1). These metabolic FGFs acquire specific structural elements that endow them with abilities to function via an endocrine mode and to bind new accessory receptors that have strict expression patterns in metabolic tissues. Although metabolic FGFs still signal through the transmembrane FGFR tyrosine kinases as the mitogenic FGFs, these new properties divert their functions to metabolic regulation. As such, FGF19, 21, and 23 drive a wide range of diverse metabolic axes that function in maintaining the homeostasis of bile acids, glucose, lipids, energy, and minerals; offsetting detrimental metabolic derangements; and achieving optimal metabolic health without an overt effect on cell proliferation and population growth. In this sense, each of the metabolic axes of FGF19, 21, and 23 stands alone as a driver of specific metabolic effects with important physiological functions and pathological consequences. Therefore, these axes together constitute the
"FGF Metabolic Axis," which is a new term that we start to call hereafter, with broad-spectrum pathophysiological roles and consequences on the quality of survival (Fig. 1).

\section{Acknowledgements}

I would like to acknowledge the long-term contributions of many members of my Wenzhou FGF team to the FGF field research as I cited in the text that made the idea of "The FGF Metabolic Axis" possible. I thank Dr. Yongde Luo for the expert assistance on the conceptual and practical aspects of the manuscript and Dr. Jin-San Zhang and Dr. Jian Xiao for their assistance. I apologize to those whose works have not been cited here due to the limited discussion scope on this evolving field. This work is supported by the National Key R\&D Program of China (No. 2017YFA0506000, Xiaokun Li).

\section{Compliance with ethics guidelines}

Xiaokun Li declares no conflict of interests. This manuscript is a review article and does not involve a research protocol requiring approval by the relevant institutional review board or ethics committee.

Open Access This article is licensed under a Creative Commons Attribution 4.0 International License, which permits use, sharing, adaptation, distribution and reproduction in any medium or format, as long as you give appropriate credit to the original author(s) and the source, provide a link to the Creative Commons licence, and indicate if changes were made.

The images or other third party material in this article are included in the article's Creative Commons licence, unless indicated otherwise in a credit line to the material. If material is not included in the article's Creative Commons licence and your intended use is not permitted by statutory regulation or exceeds the permitted use, you will need to obtain permission directly from the copyright holder.

To view a copy of this licence, visit https://creativecommons.org/ licenses/by/4.0/.

\section{References}

1. Beenken A, Mohammadi M. The FGF family: biology, pathophysiology and therapy. Nat Rev Drug Discov 2009; 8(3): 235-253

2. Luo Y, Ye S, Li X, Lu W. Emerging structure-function paradigm of endocrine FGFs in metabolic diseases. Trends Pharmacol Sci 2019; 40(2): $142-153$

3. Li X, Wang C, Xiao J, McKeehan WL, Wang F. Fibroblast growth factors, old kids on the new block. Semin Cell Dev Biol 2016; 53: 155-167

4. Eriksson AE, Cousens LS, Weaver LH, Matthews BW. Threedimensional structure of human basic fibroblast growth factor. Proc Natl Acad Sci USA 1991; 88(8): 3441-3445

5. Chen G, Liu Y, Goetz R, Fu L, Jayaraman S, Hu MC, Moe OW, Liang G, Li X, Mohammadi M. $\alpha$-Klotho is a non-enzymatic 
molecular scaffold for FGF23 hormone signalling. Nature 2018; 553(7689): 461-466

6. Degirolamo C, Sabbà C, Moschetta A. Therapeutic potential of the endocrine fibroblast growth factors FGF19, FGF21 and FGF23. Nat Rev Drug Discov 2016; 15(1): 51-69

7. Luo Y, Ye S, Chen X, Gong F, Lu W, Li X. Rush to the fire: FGF21 extinguishes metabolic stress, metaflammation and tissue damage. Cytokine Growth Factor Rev 2017; 38: 59-65

8. McKeehan WL, Wang F, Kan M. The heparan sulfate-fibroblast growth factor family: diversity of structure and function. Prog Nucleic Acid Res Mol Biol 1998; 59: 135-176

9. Itoh N, Ornitz DM. Evolution of the Fgf and Fgfr gene families. Trends Genet 2004; 20(11): 563-569

10. Itoh N, Ornitz DM. Fibroblast growth factors: from molecular evolution to roles in development, metabolism and disease. $\mathrm{J}$ Biochem 2011; 149(2): 121-130

11. Luo Y, Lu W, Li X. Unraveling endocrine FGF signaling complex to combat metabolic diseases. Trends Biochem Sci 2018; 43(8): 563-566

12. Zhang X, Ibrahimi OA, Olsen SK, Umemori H, Mohammadi M, Ornitz DM. Receptor specificity of the fibroblast growth factor family. The complete mammalian FGF family. J Biol Chem 2006; 281(23): 15694-15700

13. Armelin HA. Pituitary extracts and steroid hormones in the control of 3 T3 cell growth. Proc Natl Acad Sci USA 1973; 70(9): 27022706

14. Gospodarowicz D. Localisation of a fibroblast growth factor and its effect alone and with hydrocortisone on $3 \mathrm{~T} 3$ cell growth. Nature 1974; 249(453): 123-127

15. Burgess WH, Maciag T. The heparin-binding (fibroblast) growth factor family of proteins. Annu Rev Biochem 1989; 58(1): 575606

16. Luo Y, Ye S, Kan M, McKeehan WL. Control of fibroblast growth factor (FGF) 7- and FGF1-induced mitogenesis and downstream signaling by distinct heparin octasaccharide motifs. J Biol Chem 2006; 281(30): 21052-21061

17. Gospodarowicz D, Ill CR, Hornsby PJ, Gill GN. Control of bovine adrenal cortical cell proliferation by fibroblast growth factor. Lack of effect of epidermal growth factor. Endocrinology 1977; 100(4): 1080-1089

18. Mansour SL, Goddard JM, Capecchi MR. Mice homozygous for a targeted disruption of the proto-oncogene int-2 have developmental defects in the tail and inner ear. Development 1993; 117(1): $13-28$

19. Guo C, Sun Y, Zhou B, Adam RM, Li X, Pu WT, Morrow BE, Moon A, Li X. A Tbx1-Six1/Eya1-Fgf8 genetic pathway controls mammalian cardiovascular and craniofacial morphogenesis. J Clin Invest 2011; 121(4): 1585-1595

20. Ornitz DM, Marie PJ. Fibroblast growth factor signaling in skeletal development and disease. Genes Dev 2015; 29(14): 1463-1486

21. Kan M, Wang F, Xu J, Crabb JW, Hou J, McKeehan WL. An essential heparin-binding domain in the fibroblast growth factor receptor kinase. Science 1993; 259(5103): 1918-1921

22. Ye S, Luo Y, Lu W, Jones RB, Linhardt RJ, Capila I, Toida T, Kan M, Pelletier H, McKeehan WL. Structural basis for interaction of FGF-1, FGF-2, and FGF-7 with different heparan sulfate motifs. Biochemistry 2001; 40(48): 14429-14439
23. Goetz R, Mohammadi M. Exploring mechanisms of FGF signalling through the lens of structural biology. Nat Rev Mol Cell Biol 2013; 14(3): 166-180

24. Kouhara H, Hadari YR, Spivak-Kroizman T, Schilling J, Bar-Sagi D, Lax I, Schlessinger J. A lipid-anchored Grb2-binding protein that links FGF-receptor activation to the Ras/MAPK signaling pathway. Cell 1997; 89(5): 693-702

25. Huang Z, Marsiglia WM, Basu Roy U, Rahimi N, Ilghari D, Wang H, Chen H, Gai W, Blais S, Neubert TA, Mansukhani A, Traaseth NJ, Li X, Mohammadi M. Two FGF receptor kinase molecules act in concert to recruit and transphosphorylate phospholipase $\mathrm{C} \gamma$. Mol Cell 2016; 61(1): 98-110

26. Dorey K, Amaya E. FGF signalling: diverse roles during early vertebrate embryogenesis. Development 2010; 137(22): 37313742

27. Lu W, Luo Y, Kan M, McKeehan WL. Fibroblast growth factor10. A second candidate stromal to epithelial cell andromedin in prostate. J Biol Chem 1999; 274(18): 12827-12834

28. Jin C, Wang F, Wu X, Yu C, Luo Y, McKeehan WL. Directionally specific paracrine communication mediated by epithelial FGF9 to stromal FGFR3 in two-compartment premalignant prostate tumors. Cancer Res 2004; 64(13): 4555-4562

29. Carter EP, Fearon AE, Grose RP. Careless talk costs lives: fibroblast growth factor receptor signalling and the consequences of pathway malfunction. Trends Cell Biol 2015; 25(4): 221-233

30. Goldberg JD, Zheng J, Castro-Malaspina H, Jakubowski AA, Heller G, van den Brink MR, Perales MA. Palifermin is efficacious in recipients of TBI-based but not chemotherapy-based allogeneic hematopoietic stem cell transplants. Bone Marrow Transplant 2013; 48(1): 99-104

31. Uchi H, Igarashi A, Urabe K, Koga T, Nakayama J, Kawamori R, Tamaki K, Hirakata H, Ohura T, Furue M. Clinical efficacy of basic fibroblast growth factor (bFGF) for diabetic ulcer. Eur $\mathrm{J}$ Dermatol 2009; 19(5): 461-468

32. Akita S, Akino K, Imaizumi T, Hirano A. Basic fibroblast growth factor accelerates and improves second-degree burn wound healing. Wound Repair Regen 2008; 16(5): 635-641

33. Fu X, Shen Z, Chen Y, Xie J, Guo Z, Zhang M, Sheng Z. Randomised placebo-controlled trial of use of topical recombinant bovine basic fibroblast growth factor for second-degree burns. Lancet 1998; 352(9141): 1661-1664

34. Maddaluno L, Urwyler C, Werner S. Fibroblast growth factors: key players in regeneration and tissue repair. Development 2017; 144(22): 4047-4060

35. Zhao YZ, Zhang M, Wong HL, Tian XQ, Zheng L, Yu XC, Tian FR, Mao KL, Fan ZL, Chen PP, Li XK, Lu CT. Prevent diabetic cardiomyopathy in diabetic rats by combined therapy of aFGFloaded nanoparticles and ultrasound-targeted microbubble destruction technique. J Control Release 2016; 223: 11-21

36. Liang G, Song L, Chen Z, Qian Y, Xie J, Zhao L, Lin Q, Zhu G, Tan Y, Li X, Mohammadi M, Huang Z. Fibroblast growth factor 1 ameliorates diabetic nephropathy by an anti-inflammatory mechanism. Kidney Int 2018; 93(1): 95-109

37. Li R, Li Y, Wu Y, Zhao Y, Chen H, Yuan Y, Xu K, Zhang H, Lu Y, Wang J, Li X, Jia X, Xiao J. Heparin-poloxamer thermosensitive hydrogel loaded with bFGF and NGF enhances peripheral nerve regeneration in diabetic rats. Biomaterials 2018; 168: 24-37 
38. Wu J, Zhu J, He C, Xiao Z, Ye J, Li Y, Chen A, Zhang H, Li X, Lin L, Zhao Y, Zheng J, Xiao J. Comparative study of heparinpoloxamer hydrogel modified bFGF and aFGF for in vivo wound healing efficiency. ACS Appl Mater Interfaces 2016; 8(29): 18710-18721

39. Wu J, Ye J, Zhu J, Xiao Z, He C, Shi H, Wang Y, Lin C, Zhang H, Zhao Y, Fu X, Chen H, Li X, Li L, Zheng J, Xiao J. Heparin-based coacervate of FGF2 improves dermal regeneration by asserting a synergistic role with cell proliferation and endogenous facilitated VEGF for cutaneous wound healing. Biomacromolecules 2016; 17(6): 2168-2177

40. Wang Q, He Y, Zhao Y, Xie H, Lin Q, He Z, Wang X, Li J, Zhang H, Wang C, Gong F, Li X, Xu H, Ye Q, Xiao J. A thermosensitive heparin-poloxamer hydrogel bridges aFGF to treat spinal cord injury. ACS Appl Mater Interfaces 2017; 9(8): 6725-6745

41. Katoh M. Therapeutics targeting FGF signaling network in human diseases. Trends Pharmacol Sci 2016; 37(12): 1081-1096

42. Liang G, Liu Z, Wu J, Cai Y, Li X. Anticancer molecules targeting fibroblast growth factor receptors. Trends Pharmacol Sci 2012; 33(10): 531-541

43. Cuevas P, Carceller F, Ortega S, Zazo M, Nieto I, GiménezGallego G. Hypotensive activity of fibroblast growth factor. Science 1991; 254(5035): 1208-1210

44. Konishi M, Mikami T, Yamasaki M, Miyake A, Itoh N. Fibroblast growth factor-16 is a growth factor for embryonic brown adipocytes. J Biol Chem 2000; 275(16): 12119-12122

45. Rulifson IC, Collins P, Miao L, Nojima D, Lee KJ, Hardy M, Gupte J, Hensley K, Samayoa K, Cam C, Rottman JB, Ollmann M, Richards WG, Li Y. In vitro and in vivo analyses reveal profound effects of fibroblast growth factor 16 as a metabolic regulator. J Biol Chem 2017; 292(5): 1951-1969

46. Jonker JW, Suh JM, Atkins AR, Ahmadian M, Li P, Whyte J, He M, Juguilon H, Yin YQ, Phillips CT, Yu RT, Olefsky JM, Henry RR, Downes M, Evans RMA. A PPAR $\gamma$-FGF1 axis is required for adaptive adipose remodelling and metabolic homeostasis. Nature 2012; 485(7398): 391-394

47. Huang Z, Tan Y, Gu J, Liu Y, Song L, Niu J, Zhao L, Srinivasan L, Lin Q, Deng J, Li Y, Conklin DJ, Neubert TA, Cai L, Li X, Mohammadi M. Uncoupling the mitogenic and metabolic functions of FGF1 by tuning FGF1-FGF receptor dimer stability. Cell Reports 2017; 20(7): 1717-1728

48. Badman MK, Pissios P, Kennedy AR, Koukos G, Flier JS, Maratos-Flier E. Hepatic fibroblast growth factor 21 is regulated by PPAR $\alpha$ and is a key mediator of hepatic lipid metabolism in ketotic states. Cell Metab 2007; 5(6): 426-437

49. Inagaki $T$, Choi M, Moschetta A, Peng L, Cummins CL, McDonald JG, Luo G, Jones SA, Goodwin B, Richardson JA, Gerard RD, Repa JJ, Mangelsdorf DJ, Kliewer SA. Fibroblast growth factor 15 functions as an enterohepatic signal to regulate bile acid homeostasis. Cell Metab 2005; 2(4): 217-225

50. Inagaki T, Dutchak P, Zhao G, Ding X, Gautron L, Parameswara V, Li Y, Goetz R, Mohammadi M, Esser V, Elmquist JK, Gerard RD, Burgess SC, Hammer RE, Mangelsdorf DJ, Kliewer SA. Endocrine regulation of the fasting response by PPAR $\alpha$-mediated induction of fibroblast growth factor 21. Cell Metab 2007; 5(6): 415-425

51. Kharitonenkov A, Shiyanova TL, Koester A, Ford AM, Micanovic
R, Galbreath EJ, Sandusky GE, Hammond LJ, Moyers JS, Owens RA, Gromada J, Brozinick JT, Hawkins ED, Wroblewski VJ, Li DS, Mehrbod F, Jaskunas SR, Shanafelt AB. FGF-21 as a novel metabolic regulator. J Clin Invest 2005; 115(6): 1627-1635

52. Goetz R, Ohnishi M, Ding X, Kurosu H, Wang L, Akiyoshi J, Ma J, Gai W, Sidis Y, Pitteloud N, Kuro OM, Razzaque MS, Mohammadi M. Klotho co-receptors inhibit signaling by paracrine FGF8 subfamily ligands. Mol Cell Biol 32(10):1944-1954

53. Luo Y, Yang C, Lu W, Xie R, Jin C, Huang P, Wang F, McKeehan WL. Metabolic regulator $\beta$ Klotho interacts with fibroblast growth factor receptor 4 (FGFR4) to induce apoptosis and inhibit tumor cell proliferation. J Biol Chem 2010; 285(39): 30069-30078

54. Itoh M, Nacher JC, Kuma K, Goto S, Kanehisa M. Evolutionary history and functional implications of protein domains and their combinations in eukaryotes. Genome Biol 2007; 8(6): R121

55. Kurosu H, Choi M, Ogawa Y, Dickson AS, Goetz R, Eliseenkova AV, Mohammadi M, Rosenblatt KP, Kliewer SA, Kuro-o M. Tissue-specific expression of $\beta$ Klotho and fibroblast growth factor (FGF) receptor isoforms determines metabolic activity of FGF19 and FGF21. J Biol Chem 2007; 282(37): 26687-26695

56. Fon Tacer K, Bookout AL, Ding X, Kurosu H, John GB, Wang L, Goetz R, Mohammadi M, Kuro-o M, Mangelsdorf DJ, Kliewer SA. Research resource: comprehensive expression atlas of the fibroblast growth factor system in adult mouse. Mol Endocrinol 2010; 24(10): 2050-2064

57. Wang H, Qiang L, Farmer SR. Identification of a domain within peroxisome proliferator-activated receptor $\gamma$ regulating expression of a group of genes containing fibroblast growth factor 21 that are selectively repressed by SIRT1 in adipocytes. Mol Cell Biol 2008; 28(1): 188-200

58. Iizuka K, Takeda J, Horikawa Y. Glucose induces FGF21 mRNA expression through ChREBP activation in rat hepatocytes. FEBS Lett 2009; 583(17): 2882-2886

59. Wang Y, Solt LA, Burris TP. Regulation of FGF21 expression and secretion by retinoic acid receptor-related orphan receptor $\alpha$. J Biol Chem 2010; 285(21): 15668-15673

60. Uebanso T, Taketani Y, Yamamoto H, Amo K, Tanaka S, Arai H, Takei Y, Masuda M, Yamanaka-Okumura H, Takeda E. Liver X receptor negatively regulates fibroblast growth factor 21 in the fatty liver induced by cholesterol-enriched diet. J Nutr Biochem 2012; 23(7): 785-790

61. Masuyama R, Stockmans I, Torrekens S, Van Looveren R, Maes C, Carmeliet P, Bouillon R, Carmeliet G. Vitamin D receptor in chondrocytes promotes osteoclastogenesis and regulates FGF23 production in osteoblasts. J Clin Invest 2006; 116(12): 3150-3159

62. Kolek OI, Hines ER, Jones MD, LeSueur LK, Lipko MA, Kiela PR, Collins JF, Haussler MR, Ghishan FK. 1 $\alpha, 25$-Dihydroxyvitamin D3 upregulates FGF23 gene expression in bone: the final link in a renal-gastrointestinal-skeletal axis that controls phosphate transport. Am J Physiol Gastrointest Liver Physiol 2005; 289(6): G1036-G1042

63. Zhang Y, Lei T, Huang JF, Wang SB, Zhou LL, Yang ZQ, Chen $\mathrm{XD}$. The link between fibroblast growth factor 21 and sterol regulatory element binding protein $1 \mathrm{c}$ during lipogenesis in hepatocytes. Mol Cell Endocrinol 2011; 342(1-2): 41-47

64. Liu TF, Tang JJ, Li PS, Shen Y, Li JG, Miao HH, Li BL, Song BL. Ablation of gp78 in liver improves hyperlipidemia and insulin 
resistance by inhibiting SREBP to decrease lipid biosynthesis. Cell Metab 2012; 16(2): 213-225

65. Muise ES, Azzolina B, Kuo DW, El-Sherbeini M, Tan Y, Yuan X, $\mathrm{Mu}$ J, Thompson JR, Berger JP, Wong KK. Adipose fibroblast growth factor 21 is up-regulated by peroxisome proliferatoractivated receptor $\gamma$ and altered metabolic states. Mol Pharmacol 2008; 74(2): 403-412

66. De Sousa-Coelho AL, Marrero PF, Haro D. Activating transcription factor 4-dependent induction of FGF21 during amino acid deprivation. Biochem J 2012; 443(1): 165-171

67. Yang C, Jin C, Li X, Wang F, McKeehan WL, Luo Y. Differential specificity of endocrine FGF19 and FGF21 to FGFR1 and FGFR4 in complex with KLB. PLoS One 2012; 7(3): e33870

68. Lee S, Choi J, Mohanty J, Sousa LP, Tome F, Pardon E, Steyaert J, Lemmon MA, Lax I, Schlessinger J. Structures of $\beta$-klotho reveal a 'zip code'-like mechanism for endocrine FGF signalling. Nature 2018; 553(7689): 501-505

69. Luo Y, McKeehan WL. Stressed liver and muscle call on adipocytes with FGF21. Front Endocrinol (Lausanne) 2013; 4: 194

70. Harrison SA, Rinella ME, Abdelmalek MF, Trotter JF, Paredes AH, Arnold HL, Kugelmas M, Bashir MR, Jaros MJ, Ling L, Rossi SJ, DePaoli AM, Loomba R. NGM282 for treatment of nonalcoholic steatohepatitis: a multicentre, randomised, double-blind, placebo-controlled, phase 2 trial. Lancet 2018; 391(10126): 11741185

71. Hirschfield GM, Chazouillères O, Drenth JP, Thorburn D, Harrison SA, Landis CS, Mayo MJ, Muir AJ, Trotter JF, Leeming DJ, Karsdal MA, Jaros MJ, Ling L, Kim KH, Rossi SJ, Somaratne RM, DePaoli AM, Beuers U. Effect of NGM282, an FGF19 analogue, in primary sclerosing cholangitis: a multicenter, randomized, double-blind, placebo-controlled phase II trial. J Hepatol 2019; 70(3): 483-493

72. Harrison SA, Rossi SJ, Paredes AH, Trotter JF, Bashir MR, Guy CD, Banerjee R, Jaros MJ, Owers S, Baxter BA, Ling L, DePaoli AM. NGM282 improves liver fibrosis and histology in 12 weeks in patients with nonalcoholic steatohepatitis. Hepatology 2019 Feb 25. [Epub ahead of print] doi: 10.1002/hep.30590

73. Sanyal A, Charles ED, Neuschwander-Tetri BA, Loomba R, Harrison SA, Abdelmalek MF, Lawitz EJ, Halegoua-DeMarzio D, Kundu S, Noviello S, Luo Y, Christian R. Pegbelfermin (BMS986036), a PEGylated fibroblast growth factor 21 analogue, in patients with non-alcoholic steatohepatitis: a randomised, doubleblind, placebo-controlled, phase 2a trial. Lancet 2018; 392(10165): $2705-2717$

74. Talukdar S, Zhou Y, Li D, Rossulek M, Dong J, Somayaji V, Weng Y, Clark R, Lanba A, Owen BM, Brenner MB, Trimmer JK, Gropp KE, Chabot JR, Erion DM, Rolph TP, Goodwin B, Calle RA. A long-acting FGF21 molecule, PF-05231023, decreases body weight and improves lipid profile in non-human primates and type 2 diabetic subjects. Cell Metab 2016; 23(3): 427-440

75. Carpenter TO, Imel EA, Ruppe MD, Weber TJ, Klausner MA, Wooddell MM, Kawakami T, Ito T, Zhang X, Humphrey J, Insogna KL, Peacock M. Randomized trial of the anti-FGF23 antibody KRN23 in X-linked hypophosphatemia. J Clin Invest 2014; 124(4): 1587-1597

76. Yu C, Wang F, Kan M, Jin C, Jones RB, Weinstein M, Deng CX, McKeehan WL. Elevated cholesterol metabolism and bile acid synthesis in mice lacking membrane tyrosine kinase receptor
FGFR4. J Biol Chem 2000; 275(20): 15482-15489

77. Fu L, John LM, Adams SH, Yu XX, Tomlinson E, Renz M, Williams PM, Soriano R, Corpuz R, Moffat B, Vandlen R, Simmons L, Foster J, Stephan JP, Tsai SP, Stewart TA. Fibroblast growth factor 19 increases metabolic rate and reverses dietary and leptin-deficient diabetes. Endocrinology 2004; 145(6): 2594-2603

78. Tomlinson E, Fu L, John L, Hultgren B, Huang X, Renz M, Stephan JP, Tsai SP, Powell-Braxton L, French D, Stewart TA. Transgenic mice expressing human fibroblast growth factor-19 display increased metabolic rate and decreased adiposity. Endocrinology 2002; 143(5): 1741-1747

79. Adams AC, Yang C, Coskun T, Cheng CC, Gimeno RE, Luo Y, Kharitonenkov A. The breadth of FGF21's metabolic actions are governed by FGFR1 in adipose tissue. Mol Metab 2013; 2(1): 3137

80. Walters JR, Tasleem AM, Omer OS, Brydon WG, Dew T, le Roux CW. A new mechanism for bile acid diarrhea: defective feedback inhibition of bile acid biosynthesis. Clin Gastroenterol Hepatol 2009; 7(11):1189-1194

81. Oduyebo I, Camilleri M, Nelson AD, Khemani D, Nord SL, Busciglio I, Burton D, Rhoten D, Ryks M, Carlson P, Donato L, Lueke A, Kim K, Rossi SJ, Zinsmeister AR. Effects of NGM282, an FGF19 variant, on colonic transit and bowel function in functional constipation: a randomized phase 2 trial. Am J Gastroenterol 2018; 113(5): 725-734

82. Pai R, French D, Ma N, Hotzel K, Plise E, Salphati L, Setchell KD, Ware J, Lauriault V, Schutt L, Hartley D, Dambach D. Antibodymediated inhibition of fibroblast growth factor 19 results in increased bile acids synthesis and ileal malabsorption of bile acids in cynomolgus monkeys. Toxicol Sci 2012; 126(2): 446-456

83. Gerhard GS, Styer AM, Wood GC, Roesch SL, Petrick AT, Gabrielsen J, Strodel WE, Still CD, Argyropoulos G. A role for fibroblast growth factor 19 and bile acids in diabetes remission after Roux-en-Y gastric bypass. Diabetes Care 2013; 36(7): 18591864

84. Luo J, Ko B, Elliott M, Zhou M, Lindhout DA, Phung V, To C, Learned RM, Tian H, DePaoli AM, Ling L. A nontumorigenic variant of FGF19 treats cholestatic liver diseases. Sci Transl Med 2014; 6(247): 247ra100

85. Schaap FG, van der Gaag NA, Gouma DJ, Jansen PL. High expression of the bile salt-homeostatic hormone fibroblast growth factor 19 in the liver of patients with extrahepatic cholestasis. Hepatology 2009; 49(4): 1228-1235

86. Benoit B, Meugnier E, Castelli M, Chanon S, Vieille-Marchiset A, Durand C, Bendridi N, Pesenti S, Monternier PA, Durieux AC, Freyssenet D, Rieusset J, Lefai E, Vidal H, Ruzzin J. Fibroblast growth factor 19 regulates skeletal muscle mass and ameliorates muscle wasting in mice. Nat Med 2017; 23(8): 990-996

87. Nicholes K, Guillet S, Tomlinson E, Hillan K, Wright B, Frantz GD, Pham TA, Dillard-Telm L, Tsai SP, Stephan JP, Stinson J, Stewart T, French DM. A mouse model of hepatocellular carcinoma: ectopic expression of fibroblast growth factor 19 in skeletal muscle of transgenic mice. Am J Pathol 2002; 160(6): 2295-2307

88. Zhou M, Learned RM, Rossi SJ, DePaoli AM, Tian H, Ling L. Engineered fibroblast growth factor 19 reduces liver injury and resolves sclerosing cholangitis in Mdr2-deficient mice. Hepatology 2016; 63(3): 914-929 
89. Mayo MJ, Wigg AJ, Leggett BA, Arnold H, Thompson AJ, Weltman M, Carey EJ, Muir AJ, Ling L, Rossi SJ, DePaoli AM. NGM282 for treatment of patients with primary biliary cholangitis: a multicenter, randomized, double-blind, placebo-controlled trial. Hepatol Commun 2018; 2(9): 1037-1050

90. BonDurant LD, Potthoff MJ. Fibroblast growth factor 21: a versatile regulator of metabolic homeostasis. Annu Rev Nutr 2018; 38(1): 173-196

91. Giannini C, Feldstein AE, Santoro N, Kim G, Kursawe R, Pierpont B, Caprio S. Circulating levels of FGF-21 in obese youth: associations with liver fat content and markers of liver damage. J Clin Endocrinol Metab 2013; 98(7): 2993-3000

92. Lin Z, Gong Q, Wu C, Yu J, Lu T, Pan X, Lin S, Li X. Dynamic change of serum FGF21 levels in response to glucose challenge in human. J Clin Endocrinol Metab 2012; 97(7): E1224-E1228

93. Yilmaz Y, Eren F, Yonal O, Kurt R, Aktas B, Celikel CA, Ozdogan O, Imeryuz N, Kalayci C, Avsar E. Increased serum FGF21 levels in patients with nonalcoholic fatty liver disease. Eur J Clin Invest 2010; 40(10): 887-892

94. Kliewer SA, Mangelsdorf DJ. A dozen years of discovery: insights into the physiology and pharmacology of FGF21. Cell Metab 2019; 29(2): 246-253

95. Laeger T, Henagan TM, Albarado DC, Redman LM, Bray GA, Noland RC, Münzberg H, Hutson SM, Gettys TW, Schwartz MW, Morrison CD. FGF21 is an endocrine signal of protein restriction. J Clin Invest 2014; 124(9): 3913-3922

96. Fisher FM, Kim M, Doridot L, Cunniff JC, Parker TS, Levine DM, Hellerstein MK, Hudgins LC, Maratos-Flier E, Herman MA. A critical role for ChREBP-mediated FGF21 secretion in hepatic fructose metabolism. Mol Metab 2017; 6(1): 14-21

97. von Holstein-Rathlou S, BonDurant LD, Peltekian L, Naber MC, Yin TC, Claflin KE, Urizar AI, Madsen AN, Ratner C, Holst B, Karstoft K, Vandenbeuch A, Anderson CB, Cassell MD, Thompson AP, Solomon TP, Rahmouni K, Kinnamon SC, Pieper AA, Gillum MP, Potthoff MJ. FGF21 mediates endocrine control of simple sugar intake and sweet taste preference by the liver. Cell Metab 2016; 23(2): 335-343

98. Talukdar S, Owen BM, Song P, Hernandez G, Zhang Y, Zhou Y, Scott WT, Paratala B, Turner T, Smith A, Bernardo B, Müller CP, Tang H, Mangelsdorf DJ, Goodwin B, Kliewer SA. FGF21 regulates sweet and alcohol preference. Cell Metab 2016; 23(2): 344-349

99. Fisher FM, Chui PC, Nasser IA, Popov Y, Cunniff JC, Lundasen T, Kharitonenkov A, Schuppan D, Flier JS and Maratos-Flier E. Fibroblast growth factor 21 limits lipotoxicity by promoting hepatic fatty acid activation in mice on methionine and cholinedeficient diets. Gastroenterology 2014; 147(5): 1073-1083.e6

100. Huang X, Yu C, Jin C, Yang C, Xie R, Cao D, Wang F, McKeehan WL. Forced expression of hepatocyte-specific fibroblast growth factor 21 delays initiation of chemically induced hepatocarcinogenesis. Mol Carcinog 2006; 45(12): 934-942

101. Tanaka N, Takahashi S, Zhang Y, Krausz KW, Smith PB, Patterson $\mathrm{AD}$, Gonzalez FJ. Role of fibroblast growth factor 21 in the early stage of NASH induced by methionine- and choline-deficient diet. Biochim Biophys Acta 2015; 1852(7): 1242-1252

102. Desai BN, Singhal G, Watanabe M, Stevanovic D, Lundasen T, Fisher FM, Mather ML, Vardeh HG, Douris N, Adams AC, Nasser
IA, FitzGerald GA, Flier JS, Skarke C, Maratos-Flier E. Fibroblast growth factor 21 (FGF21) is robustly induced by ethanol and has a protective role in ethanol associated liver injury. Mol Metab 2017; 6(11): 1395-1406

103. Ye D, Wang Y, Li H, Jia W, Man K, Lo CM, Wang Y, Lam KS, Xu A. Fibroblast growth factor 21 protects against acetaminopheninduced hepatotoxicity by potentiating peroxisome proliferatoractivated receptor coactivator protein- $1 \alpha$-mediated antioxidant capacity in mice. Hepatology 2014; 60(3): 977-989

104. Singhal G, Kumar G, Chan S, Fisher FM, Ma Y, Vardeh HG, Nasser IA, Flier JS, Maratos-Flier E. Deficiency of fibroblast growth factor 21 (FGF21) promotes hepatocellular carcinoma (HCC) in mice on a long term obesogenic diet. Mol Metab 2018; 13: 56-66

105. Ye M, Lu W, Wang X, Wang C, Abbruzzese JL, Liang G, Li X, Luo Y. FGF21-FGFR1 coordinates phospholipid homeostasis, lipid droplet function, and ER stress in obesity. Endocrinology 2016; 157(12): 4754-4769

106. Foltz IN, Hu S, King C, Wu X, Yang C, Wang W, Weiszmann J, Stevens J, Chen JS, Nuanmanee N, Gupte J, Komorowski R, Sekirov L, Hager T, Arora T, Ge H, Baribault H, Wang F, Sheng J, Karow M, Wang M, Luo Y, McKeehan W, Wang Z, Véniant MM, Li Y. Treating diabetes and obesity with an FGF21-mimetic antibody activating the $\beta$ Klotho/FGFR1c receptor complex. Sci Transl Med 2012; 4(162): 162ra153

107. Gaich G, Chien JY, Fu H, Glass LC, Deeg MA, Holland WL, Kharitonenkov A, Bumol T, Schilske HK, Moller DE. The effects of LY2405319, an FGF21 analog, in obese human subjects with type 2 diabetes. Cell Metab 2013; 18(3): 333-340

108. Lin Z, Tian H, Lam KS, Lin S, Hoo RC, Konishi M, Itoh N, Wang Y, Bornstein SR, Xu A, Li X. Adiponectin mediates the metabolic effects of FGF21 on glucose homeostasis and insulin sensitivity in mice. Cell Metab 2013; 17(5): 779-789

109. Huang Z, Zhong L, Lee JTH, Zhang J, Wu D, Geng L, Wang Y, Wong CM, Xu A. The FGF21-CCL11 axis mediates beiging of white adipose tissues by coupling sympathetic nervous system to type 2 immunity. Cell Metab 2017; 26(3): 493-508.e4

110. Lee P, Linderman JD, Smith S, Brychta RJ, Wang J, Idelson C, Perron RM, Werner CD, Phan GQ, Kammula US, Kebebew E, Pacak K, Chen KY, Celi FS. Irisin and FGF21 are cold-induced endocrine activators of brown fat function in humans. Cell Metab 2014; 19(2): 302-309

111. Hondares E, Iglesias R, Giralt A, Gonzalez FJ, Giralt M, Mampel $\mathrm{T}$, Villarroya F. Thermogenic activation induces FGF21 expression and release in brown adipose tissue. J Biol Chem 2011; 286(15): 12983-12990

112. Ameka M, Markan KR, Morgan DA, BonDurant LD, Idiga SO, Naber MC, Zhu Z, Zingman LV, Grobe JL, Rahmouni K, Potthoff MJ. Liver derived FGF21 maintains core body temperature during acute cold exposure. Sci Rep 2019; 9(1): 630

113. Zhang Y, Xie Y, Berglund ED, Coate KC, He TT, Katafuchi T, Xiao G, Potthoff MJ, Wei W, Wan Y, Yu RT, Evans RM, Kliewer SA, Mangelsdorf DJ. The starvation hormone, fibroblast growth factor-21, extends lifespan in mice. eLife 2012; 1: e00065

114. Youm YH, Horvath TL, Mangelsdorf DJ, Kliewer SA, Dixit VD. Prolongevity hormone FGF21 protects against immune senescence by delaying age-related thymic involution. Proc Natl Acad Sci 
USA 2016; 113(4): 1026-1031

115. Adams AC, Coskun T, Cheng CC, O'Farrell LS, Dubois SL, Kharitonenkov A. Fibroblast growth factor 21 is not required for the antidiabetic actions of the thiazoladinediones. Mol Metab 2013; 2(3): 205-214

116. Coate KC, Hernandez G, Thorne CA, Sun S, Le TDV, Vale K, Kliewer SA, Mangelsdorf DJ. FGF21 is an exocrine pancreas secretagogue. Cell Metab 2017; 25(2): 472-480

117. Singhal G, Fisher FM, Chee MJ, Tan TG, El Ouaamari A, Adams AC, Najarian R, Kulkarni RN, Benoist C, Flier JS, Maratos-Flier E. Fibroblast growth factor 21 (FGF21) protects against high fat diet induced inflammation and islet hyperplasia in pancreas. PLoS One 2016; 11(2): e0148252

118. Johnson CL, Mehmood R, Laing SW, Stepniak CV, Kharitonenkov A, Pin CL. Silencing of the fibroblast growth factor 21 gene is an underlying cause of acinar cell injury in mice lacking MIST1. Am J Physiol Endocrinol Metab 2014; 306(8): E916-E928

119. Johnson CL, Weston JY, Chadi SA, Fazio EN, Huff MW, Kharitonenkov A, Köester A, Pin CL. Fibroblast growth factor 21 reduces the severity of cerulein-induced pancreatitis in mice. Gastroenterology 2009; 137(5): 1795-1804

120. Kuroda M, Muramatsu R, Maedera N, Koyama Y, Hamaguchi M, Fujimura H, Yoshida M, Konishi M, Itoh N, Mochizuki $H$, Yamashita T. Peripherally derived FGF21 promotes remyelination in the central nervous system. J Clin Invest 2017; 127(9): 34963509

121. Soberg S, Sandholt CH, Jespersen NZ, Toft U, Madsen AL, von Holstein-Rathlou S, Grevengoed TJ, Christensen KB, Bredie WLP, Potthoff MJ, Solomon TPJ, Scheele C, Linneberg A, Jorgensen T, Pedersen O, Hansen T, Gillum MP, Grarup N. FGF21 is a sugar-induced hormone associated with sweet intake and preference in humans. Cell Metab 2017; 25(5): 1045-1053.e6

122. Song P, Zechner C, Hernandez G, Canovas J, Xie Y, Sondhi V, Wagner M, Stadlbauer V, Horvath A, Leber B, Hu MC, Moe OW, Mangelsdorf DJ, Kliewer SA. The hormone FGF21 stimulates water drinking in response to ketogenic diet and alcohol. Cell Metab 2018; 27(6): 1338-1347.e4

123. Frayling TM, Beaumont RN, Jones SE, Yaghootkar H, Tuke MA, Ruth KS, Casanova F, West B, Locke J, Sharp S, Ji Y, Thompson W, Harrison J, Etheridge AS, Gallins PJ, Jima D, Wright F, Zhou Y, Innocenti F, Lindgren CM, Grarup N, Murray A, Freathy RM, Weedon MN, Tyrrell J, Wood AR. A common allele in FGF21 associated with sugar intake is associated with body shape, lower total body-fat percentage, and higher blood pressure. Cell Reports 2018; 23(2): 327-336

124. Schumann G, Liu C, O’Reilly P, Gao H, Song P, Xu B, Ruggeri B, Amin N, Jia T, Preis S, Segura Lepe M, Akira S, Barbieri C, Baumeister S, Cauchi S, Clarke TK, Enroth S, Fischer K, Hällfors J, Harris SE, Hieber S, Hofer E, Hottenga JJ, Johansson Å, Joshi PK, Kaartinen N, Laitinen J, Lemaitre R, Loukola A, Luan J, Lyytikäinen LP, Mangino M, Manichaikul A, Mbarek H, Milaneschi Y, Moayyeri A, Mukamal K, Nelson C, Nettleton J, Partinen E, Rawal R, Robino A, Rose L, Sala C, Satoh T, Schmidt R, Schraut K, Scott R, Smith AV, Starr JM, Teumer A, Trompet S, Uitterlinden AG, Venturini C, Vergnaud AC, Verweij N, Vitart V, Vuckovic D, Wedenoja J, Yengo L, Yu B, Zhang W, Zhao JH, Boomsma DI, Chambers J, Chasman DI, Daniela T, de Geus E, Deary I, Eriksson JG, Esko T, Eulenburg V, Franco OH, Froguel P,
Gieger C, Grabe HJ, Gudnason V, Gyllensten U, Harris TB, Hartikainen AL, Heath AC, Hocking L, Hofman A, Huth C, Jarvelin MR, Jukema JW, Kaprio J, Kooner JS, Kutalik Z, Lahti J, Langenberg C, Lehtimäki T, Liu Y, Madden PA, Martin N, Morrison A, Penninx B, Pirastu N, Psaty B, Raitakari O, Ridker P, Rose R, Rotter JI, Samani NJ, Schmidt H, Spector TD, Stott D, Strachan D, Tzoulaki I, van der Harst P, van Duijn CM, MarquesVidal P, Vollenweider P, Wareham NJ, Whitfield JB, Wilson J, Wolffenbuttel B, Bakalkin G, Evangelou E, Liu Y, Rice KM, Desrivières S, Kliewer SA, Mangelsdorf DJ, Müller CP, Levy D, Elliott $\mathrm{P}$. KLB is associated with alcohol drinking, and its gene product $\beta$-Klotho is necessary for FGF21 regulation of alcohol preference. Proc Natl Acad Sci USA 2016; 113(50): 14372-14377

125. Restelli LM, Oettinghaus B, Halliday M, Agca C, Licci M, Sironi L, Savoia C, Hench J, Tolnay M, Neutzner A, Schmidt A, Eckert A, Mallucci G, Scorrano L, Frank S. Neuronal mitochondrial dysfunction activates the integrated stress response to induce fibroblast growth factor 21. Cell Reports 2018; 24(6): 1407-1414

126. Planavila A, Redondo I, Hondares E, Vinciguerra M, Munts C, Iglesias R, Gabrielli LA, Sitges M, Giralt M, van Bilsen M, Villarroya F. Fibroblast growth factor 21 protects against cardiac hypertrophy in mice. Nat Commun 2013; 4(1): 2019

127. Morville T, Sahl RE, Trammell SA, Svenningsen JS, Gillum MP, Helge JW, Clemmensen C. Divergent effects of resistance and endurance exercise on plasma bile acids, FGF19, and FGF21 in humans. JCI Insight 2018; 3(15): 122737

128. Brahma MK, Adam RC, Pollak NM, Jaeger D, Zierler KA, Pöcher N, Schreiber R, Romauch M, Moustafa T, Eder S, Ruelicke T, Preiss-Landl K, Lass A, Zechner R, Haemmerle G. Fibroblast growth factor 21 is induced upon cardiac stress and alters cardiac lipid homeostasis. J Lipid Res 2014; 55(11): 2229-2241

129. Lin Z, Pan X, Wu F, Ye D, Zhang Y, Wang Y, Jin L, Lian Q, Huang Y, Ding H, Triggle C, Wang K, Li X, Xu A. Fibroblast growth factor 21 prevents atherosclerosis by suppression of hepatic sterol regulatory element-binding protein-2 and induction of adiponectin in mice. Circulation 2015; 131(21): 1861-1871

130. Liu SQ, Roberts D, Kharitonenkov A, Zhang B, Hanson SM, Li YC, Zhang LQ, Wu YH. Endocrine protection of ischemic myocardium by FGF21 from the liver and adipose tissue. Sci Rep 2013; 3(1): 2767

131. Yang H, Feng A, Lin S, Yu L, Lin X, Yan X, Lu X, Zhang C. Fibroblast growth factor-21 prevents diabetic cardiomyopathy via AMPK-mediated antioxidation and lipid-lowering effects in the heart. Cell Death Dis 2018; 9(2): 227

132. Zhang C, Huang Z, Gu J, Yan X, Lu X, Zhou S, Wang S, Shao M, Zhang F, Cheng P, Feng W, Tan Y, Li X. Fibroblast growth factor 21 protects the heart from apoptosis in a diabetic mouse model via extracellular signal-regulated kinase 1/2-dependent signalling pathway. Diabetologia 2015; 58(8): 1937-1948

133. Pan X, Shao Y, Wu F, Wang Y, Xiong R, Zheng J, Tian H, Wang B, Wang Y, Zhang Y, Han Z, Qu A, Xu H, Lu A, Yang T, Li X, Xu A, Du J, Lin Z.FGF21 prevents angiotensin II-induced hypertension and vascular dysfunction by activation of ACE2/angiotensin(1-7) axis in mice. Cell Metab 2018; 27(6): 1323-1337.e5

134. Kim KH, Jeong YT, Oh H, Kim SH, Cho JM, Kim YN, Kim SS, Kim DH, Hur KY, Kim HK, Ko T, Han J, Kim HL, Kim J, Back SH, Komatsu M, Chen H, Chan DC, Konishi M, Itoh N, Choi CS, Lee MS. Autophagy deficiency leads to protection from obesity 
and insulin resistance by inducing Fgf 21 as a mitokine. Nat Med 2013; 19(1): 83-92

135. Suomalainen A, Elo JM, Pietiläinen KH, Hakonen AH, Sevastianova K, Korpela M, Isohanni P, Marjavaara SK, Tyni T, KiuruEnari S, Pihko H, Darin N, Õunap K, Kluijtmans LA, Paetau A, Buzkova J, Bindoff LA, Annunen-Rasila J, Uusimaa J, Rissanen A, Yki-Järvinen H, Hirano M, Tulinius M, Smeitink J, Tyynismaa H. FGF-21 as a biomarker for muscle-manifesting mitochondrial respiratory chain deficiencies: a diagnostic study. Lancet Neurol 2011; 10(9): 806-818

136. Geng L, Liao B, Jin L, Huang Z, Triggle CR, Ding H, Zhang J, Huang $\mathrm{Y}$, Lin $\mathrm{Z}, \mathrm{Xu}$ A. Exercise alleviates obesity-induced metabolic dysfunction via enhancing FGF21 sensitivity in adipose tissues. Cell Rep 2019; 26(10): 2738-2752.e4

137. Pereira RO, Tadinada SM, Zasadny FM, Oliveira KJ, Pires KMP, Olvera A, Jeffers J, Souvenir R, Mcglauflin R, Seei A, Funari T, Sesaki H, Potthoff MJ, Adams CM, Anderson EJ, Abel ED. OPA1 deficiency promotes secretion of FGF21 from muscle that prevents obesity and insulin resistance. EMBO J 2017; 36(14): 2126-2145

138. Tanimura Y, Aoi W, Takanami Y, Kawai Y, Mizushima K, Naito Y, Yoshikawa T. Acute exercise increases fibroblast growth factor 21 in metabolic organs and circulation. Physiol Rep 2016; 4(12): e12828

139. Lee MS, Choi SE, Ha ES, An SY, Kim TH, Han SJ, Kim HJ, Kim DJ, Kang Y, Lee KW. Fibroblast growth factor-21 protects human skeletal muscle myotubes from palmitate-induced insulin resistance by inhibiting stress kinase and NF- $\mathrm{BB}$. Metabolism 2012; 61(8): 1142-1151

140. Izumiya Y, Bina HA, Ouchi N, Akasaki Y, Kharitonenkov A, Walsh K. FGF21 is an Akt-regulated myokine. FEBS Lett 2008; 582(27): 3805-3810

141. Owen BM, Ding X, Morgan DA, Coate KC, Bookout AL, Rahmouni K, Kliewer SA, Mangelsdorf DJ. FGF21 acts centrally to induce sympathetic nerve activity, energy expenditure, and weight loss. Cell Metab 2014; 20(4): 670-677

142. Douris N, Stevanovic DM, Fisher FM, Cisu TI, Chee MJ, Nguyen NL, Zarebidaki E, Adams AC, Kharitonenkov A, Flier JS, Bartness TJ, Maratos-Flier E. Central fibroblast growth factor 21 browns white fat via sympathetic action in male mice. Endocrinology 2015; 156(7): 2470-2481

143. Liang Q, Zhong L, Zhang J, Wang Y, Bornstein SR, Triggle CR, Ding H, Lam KS, Xu A. FGF21 maintains glucose homeostasis by mediating the cross talk between liver and brain during prolonged fasting. Diabetes 2014; 63(12): 4064-4075

144. Owen BM, Bookout AL, Ding X, Lin VY, Atkin SD, Gautron L, Kliewer SA, Mangelsdorf DJ. FGF21 contributes to neuroendocrine control of female reproduction. Nat Med 2013; 19(9): 11531156

145. Bookout AL, de Groot MH, Owen BM, Lee S, Gautron L, Lawrence HL, Ding X, Elmquist JK, Takahashi JS, Mangelsdorf DJ, Kliewer SA. FGF21 regulates metabolism and circadian behavior by acting on the nervous system. Nat Med 2013; 19(9): $1147-1152$

146. Ishida N. Role of PPAR $\alpha$ in the control of torpor through FGF21NPY pathway: from circadian clock to seasonal change in mammals. PPAR Res 2009; 2009: 412949

147. Wang Q, Yuan J, Yu Z, Lin L, Jiang Y, Cao Z, Zhuang P, Whalen
MJ, Song B, Wang XJ, Li X, Lo EH, Xu Y, Wang X. FGF21 attenuates high-fat diet-induced cognitive impairment via metabolic regulation and anti-inflammation of obese mice. Mol Neurobiol 2018; 55(6): 4702-4717

148. Yu Y, Bai F, Wang W, Liu Y, Yuan Q, Qu S, Zhang T, Tian G, Li S, Li D, Ren G. Fibroblast growth factor 21 protects mouse brain against D-galactose induced aging via suppression of oxidative stress response and advanced glycation end products formation. Pharmacol Biochem Behav 2015; 133: 122-131

149. Sarruf DA, Thaler JP, Morton GJ, German J, Fischer JD, Ogimoto K, Schwartz MW. Fibroblast growth factor 21 action in the brain increases energy expenditure and insulin sensitivity in obese rats. Diabetes 2010; 59(7): 1817-1824

150. Véniant MM, Hale C, Helmering J, Chen MM, Stanislaus S, Busby J, Vonderfecht S, Xu J, Lloyd DJ. FGF21 promotes metabolic homeostasis via white adipose and leptin in mice. PLoS One 2012; 7(7): e40164

151. Xu J, Lloyd DJ, Hale C, Stanislaus S, Chen M, Sivits G, Vonderfecht S, Hecht R, Li YS, Lindberg RA, Chen JL, Jung DY, Zhang Z, Ko HJ, Kim JK, Véniant MM. Fibroblast growth factor 21 reverses hepatic steatosis, increases energy expenditure, and improves insulin sensitivity in diet-induced obese mice. Diabetes 2009; 58(1): 250-259

152. So WY, Cheng Q, Xu A, Lam KS, Leung PS. Loss of fibroblast growth factor 21 action induces insulin resistance, pancreatic islet hyperplasia and dysfunction in mice. Cell Death Dis 2015; 6(3): e1707

153. Zhang C, Shao M, Yang H, Chen L, Yu L, Cong W, Tian H, Zhang F, Cheng P, Jin L, Tan Y, Li X, Cai L, Lu X. Attenuation of hyperlipidemia- and diabetes-induced early-stage apoptosis and late-stage renal dysfunction via administration of fibroblast growth factor-21 is associated with suppression of renal inflammation. PLoS One 2013; 8(12): e82275

154. Kim HW, Lee JE, Cha JJ, Hyun YY, Kim JE, Lee MH, Song HK, Nam DH, Han JY, Han SY, Han KH, Kang YS, Cha DR. Fibroblast growth factor 21 improves insulin resistance and ameliorates renal injury in $d b / d b$ mice. Endocrinology 2013; 154(9): 3366-3376

155. Tang TT, Li YY, Li JJ, Wang K, Han Y, Dong WY, Zhu ZF, Xia N, Nie SF, Zhang M, Zeng ZP, Lv BJ, Jiao J, Liu H, Xian ZS, Yang XP, Hu Y, Liao YH, Wang Q, Tu X, Mallat Z, Huang Y, Shi GP, Cheng X. Liver-heart crosstalk controls IL-22 activity in cardiac protection after myocardial infarction. Theranostics 2018; 8(16): $4552-4562$

156. Wang N, Zhao TT, Li SM, Li YH, Wang YJ, Li DS, Wang WF. Fibroblast growth factor 21 ameliorates pancreatic fibrogenesis via regulating polarization of macrophages. Exp Cell Res 2019; 382 (1): 111457

157. Li S, Guo X, Zhang T, Wang N, Li J, Xu P, Zhang S, Ren G, Li D. Fibroblast growth factor 21 ameliorates high glucose-induced fibrogenesis in mesangial cells through inhibiting STAT5 signaling pathway. Biomed Pharmacother 2017; 93: 695-704

158. Li S, Wang N, Guo X, Li J, Zhang T, Ren G, Li D. Fibroblast growth factor 21 regulates glucose metabolism in part by reducing renal glucose reabsorption. Biomed Pharmacother 2018; 108: 355366

159. Lin XL, He XL, Zeng JF, Zhang H, Zhao Y, Tan JK, Wang Z. 
FGF21 increases cholesterol efflux by upregulating ABCA1 through the ERK1/2-PPAR $\gamma-\mathrm{LXR} \alpha$ pathway in THP1 macrophage-derived foam cells. DNA Cell Biol 2014; 33(8): 514-521

160. Yu Y, He J, Li S, Song L, Guo X, Yao W, Zou D, Gao X, Liu Y, Bai F, Ren G, Li D. Fibroblast growth factor 21 (FGF21) inhibits macrophage-mediated inflammation by activating $\mathrm{Nrf} 2$ and suppressing the NF- $\mathrm{B}$ signaling pathway. Int Immunopharmacol 2016; 38: 144-152

161. Li H, Wu G, Fang Q, Zhang M, Hui X, Sheng B, Wu L, Bao Y, Li $\mathrm{P}, \mathrm{Xu} \mathrm{A}$, Jia W. Fibroblast growth factor 21 increases insulin sensitivity through specific expansion of subcutaneous fat. Nat Commun 2018; 9(1): 272

162. Li SM, Wang WF, Zhou LH, Ma L, An Y, Xu WJ, Li TH, Yu YH, Li DS, Liu Y. Fibroblast growth factor 21 expressions in white blood cells and sera of patients with gestational diabetes mellitus during gestation and postpartum. Endocrine 2015; 48(2): 519-527

163. Li JY, Wang N, Khoso MH, Shen CB, Guo MZ, Pang XX, Li DS, Wang WF. FGF-21 elevated IL-10 production to correct LPSinduced inflammation. Inflammation 2018; 41(3): 751-759

164. Wang WF, Ma L, Liu MY, Zhao TT, Zhang T, Yang YB, Cao HX, Han XH, Li DS. A novel function for fibroblast growth factor 21: stimulation of NADPH oxidase-dependent ROS generation. Endocrine 2015; 49(2): 385-395

165. Li SM, Yu YH, Li L, Wang WF, Li DS. Treatment of CIA mice with FGF21 down-regulates TH17-IL-17 axis. Inflammation 2016; 39(1): 309-319

166. Saito H, Kusano K, Kinosaki M, Ito H, Hirata M, Segawa H, Miyamoto K, Fukushima N. Human fibroblast growth factor-23 mutants suppress $\mathrm{Na}^{+}$-dependent phosphate co-transport activity and 1 $\alpha, 25$-dihydroxyvitamin D3 production. J Biol Chem 2003; 278(4): 2206-2211

167. Shimada T, Kakitani M, Yamazaki Y, Hasegawa H, Takeuchi Y, Fujita T, Fukumoto S, Tomizuka K, Yamashita T. Targeted ablation of Fgf23 demonstrates an essential physiological role of FGF23 in phosphate and vitamin D metabolism. J Clin Invest 2004; 113(4): 561-568

168. Shimada T, Mizutani S, Muto T, Yoneya T, Hino R, Takeda S, Takeuchi Y, Fujita T, Fukumoto S, Yamashita T. Cloning and characterization of FGF23 as a causative factor of tumor-induced osteomalacia. Proc Natl Acad Sci USA 2001; 98(11): 6500-6505

169. Andrukhova O, Smorodchenko A, Egerbacher M, Streicher C, Zeitz U, Goetz R, Shalhoub V, Mohammadi M, Pohl EE, Lanske B, Erben RG. FGF23 promotes renal calcium reabsorption through the TRPV5 channel. EMBO J 2014; 33(3): 229-246

170. Andrukhova O, Slavic S, Smorodchenko A, Zeitz U, Shalhoub V, Lanske B, Pohl EE, Erben RG. FGF23 regulates renal sodium handling and blood pressure. EMBO Mol Med 2014; 6(6): 744759

171. Ben-Dov IZ, Galitzer H, Lavi-Moshayoff V, Goetz R, Kuro-o M, Mohammadi M, Sirkis R, Naveh-Many T, Silver J. The parathyroid is a target organ for FGF23 in rats. J Clin Invest 2007; 117(12): 4003-4008

172. Toro L, Barrientos V, León P, Rojas M, Gonzalez M, GonzálezIbáñez A, Illanes S, Sugikawa K, Abarzúa N, Bascuñán C, Arcos K, Fuentealba C, Tong AM, Elorza AA, Pinto ME, Alzamora R, Romero C, Michea L. Erythropoietin induces bone marrow and plasma fibroblast growth factor 23 during acute kidney injury.
Kidney Int 2018; 93(5): 1131-1141

173. Rabadi S, Udo I, Leaf DE, Waikar SS, Christov M. Acute blood loss stimulates fibroblast growth factor 23 production. Am J Physiol Renal Physiol 2018; 314(1): F132-F139

174. ADHR Consortium. Autosomal dominant hypophosphataemic rickets is associated with mutations in FGF23. Nat Genet 2000; 26(3): 345-348

175. Bowe AE, Finnegan R, Jan de Beur SM, Cho J, Levine MA, Kumar R, Schiavi SC. FGF-23 inhibits renal tubular phosphate transport and is a PHEX substrate. Biochem Biophys Res Commun 2001; 284(4): 977-981

176. Riminucci M, Collins MT, Fedarko NS, Cherman N, Corsi A, White KE, Waguespack S, Gupta A, Hannon T, Econs MJ, Bianco P, Gehron Robey P. FGF-23 in fibrous dysplasia of bone and its relationship to renal phosphate wasting. J Clin Invest 2003; 112(5): 683-692

177. Hoffman WH, Jueppner HW, Deyoung BR, O'dorisio MS, Given KS. Elevated fibroblast growth factor-23 in hypophosphatemic linear nevus sebaceous syndrome. Am J Med Genet A 2005; 134(3): 233-236

178. Kato K, Jeanneau C, Tarp MA, Benet-Pagès A, Lorenz-Depiereux B, Bennett EP, Mandel U, Strom TM, Clausen H. Polypeptide GalNAc-transferase T3 and familial tumoral calcinosis. Secretion of fibroblast growth factor 23 requires O-glycosylation. J Biol Chem 2006; 281(27): 18370-18377

179. Ichikawa S, Imel EA, Sorenson AH, Severe R, Knudson P, Harris GJ, Shaker JL, Econs MJ. Tumoral calcinosis presenting with eyelid calcifications due to novel missense mutations in the glycosyl transferase domain of the GALNT3 gene. J Clin Endocrinol Metab 2006; 91(11): 4472-4475

180. Garringer HJ, Fisher C, Larsson TE, Davis SI, Koller DL, Cullen MJ, Draman MS, Conlon N, Jain A, Fedarko NS, Dasgupta B, White KE. The role of mutant UDP-N-acetyl- $\alpha$-D-galactosaminepolypeptide $\mathrm{N}$-acetylgalactosaminyltransferase 3 in regulating serum intact fibroblast growth factor 23 and matrix extracellular phosphoglycoprotein in heritable tumoral calcinosis. J Clin Endocrinol Metab 2006; 91(10): 4037-4042

181. Benet-Pagès A, Orlik P, Strom TM, Lorenz-Depiereux B. An FGF23 missense mutation causes familial tumoral calcinosis with hyperphosphatemia. Hum Mol Genet 2005; 14(3): 385-390

182. Chefetz I, Heller R, Galli-Tsinopoulou A, Richard G, Wollnik B, Indelman M, Koerber F, Topaz O, Bergman R, Sprecher E, Schoenau E. A novel homozygous missense mutation in FGF23 causes Familial Tumoral Calcinosis associated with disseminated visceral calcification. Hum Genet 2005; 118(2): 261-266

183. Araya K, Fukumoto S, Backenroth R, Takeuchi Y, Nakayama K, Ito N, Yoshii N, Yamazaki Y, Yamashita T, Silver J, Igarashi T, Fujita T. A novel mutation in fibroblast growth factor 23 gene as a cause of tumoral calcinosis. J Clin Endocrinol Metab 2005; 90(10): $5523-5527$

184. Abbasi F, Ghafouri-Fard S, Javaheri M, Dideban A, Ebrahimi A, Ebrahim-Habibi A. A new missense mutation in FGF23 gene in a male with hyperostosis-hyperphosphatemia syndrome (HHS). Gene 2014; 542(2): 269-271

185. Faul C, Amaral AP, Oskouei B, Hu MC, Sloan A, Isakova T, Gutiérrez OM, Aguillon-Prada R, Lincoln J, Hare JM, Mundel P, Morales A, Scialla J, Fischer M, Soliman EZ, Chen J, Go AS, 
Rosas SE, Nessel L, Townsend RR, Feldman HI, St John Sutton M, Ojo A, Gadegbeku C, Di Marco GS, Reuter S, Kentrup D, Tiemann K, Brand M, Hill JA, Moe OW, Kuro-O M, Kusek JW, Keane MG, Wolf M. FGF23 induces left ventricular hypertrophy. J Clin Invest 2011; 121(11): 4393-4408

186. Gutiérrez OM, Januzzi JL, Isakova T, Laliberte K, Smith K, Collerone G, Sarwar A, Hoffmann U, Coglianese E, Christenson R, Wang TJ, deFilippi C, Wolf M. Fibroblast growth factor 23 and left ventricular hypertrophy in chronic kidney disease. Circulation
2009; 119(19): 2545-2552

187. McGrath ER, Himali JJ, Levy D, Conner SC, Pase MP, Abraham CR, Courchesne P, Satizabal CL, Vasan RS, Beiser AS, Seshadri S. Circulating fibroblast growth factor 23 levels and incident dementia: The Framingham heart study. PLoS One 2019; 14(3): e0213321

188. Liu P, Chen L, Bai X, Karaplis A, Miao D, Gu N. Impairment of spatial learning and memory in transgenic mice overexpressing human fibroblast growth factor-23. Brain Res 2011; 1412: 9-17 